\title{
Governance: Key for Environmental Sustainability in the Hindu Kush Himalaya
}

Coordinating Lead Authors

Hemant Raj Ojha, University of New South Wales, Institute for Studies and Development Worldwide (IFSD), Australia, e-mail: ojhahemant1@gmail.com

Rucha Ghate, International Centre for Integrated Mountain Development, Kathmandu, Nepal,

e-mail: ruchaghate@gmail.com (corresponding author)

Lam Dorji, Centre for Environment and Development, Thimphu, Bhutan, e-mail: 1dorjie@gmail.com

\section{Lead Authors}

Ankita Shrestha, Southasia Institute of Advanced Studies, Kathmandu, Nepal, e-mail: anki.shrestha@gmail.com

Dinesh Paudel, Appalachian State University, USA, e-mail: paudeld@appstate.edu

Andrea Nightingale, Swedish University of Agricultural Sciences, Uppsala, and Norwegian University of Life Sciences, Sweden, e-mail: andrea.nightingale@slu.se

Krishna Shrestha, University of New South Wales, Australia, e-mail: krishna.shrestha@unsw.edu.au Muhammad Arif Watto, University of Agriculture, Faisalabad, Pakistan, e-mail: arif.watto@uaf.edu.pk Rajan Kotru, International Centre for Integrated Mountain Development, Nepal,

e-mail: rajan.kotru@icimod.org

\section{Contributing Authors}

Jun He, Yunnan University, China, e-mail: Jun.he@ynu.edu.cn

Aung Kyaw Naing, RECOFTC - The Center for People and Forests, country program, Myanmar, e-mail: aungkyawnaing@ recoftc.org

Tashi Wangmo, National Council of Bhutan, Bhutan, e-mail: tashiwangmo2002@yahoo.com Vishal Narain, Management Development Institute, Gurgaon, India, e-mail: vishalnarain@mdi.ac.in Anamika Barua, Dept of Humanities and Social Sciences, IIT Guwahati, India, e-mail: anamika.barua@gmail.com

Babar Shahbaz, University of Agriculture, Faisalabad, Pakistan, e-mail: bsuaf@yahoo.com Bimal Regmi, International Centre for Integrated Mountain Development, Nepal, e-mail: bimalrocks@yahoo.com

Niaz Ahmed Khan, University of Dhaka, Bangladesh, e-mail: khan.niaz.ahmed@gmail.com Binod Chapagain, RECOFTC - The Center for People and Forests, Bangkok, Thailand, e-mail: binod.chapagain@recoftc.org

\section{Review Editor}

Philippus Wester, International Centre for Integrated Mountain Development, Kathmandu, Nepal, e-mail: philippus.wester@icimod.org

\section{Corresponding Author}

Rucha Ghate, International Centre for Integrated Mountain Development, Kathmandu, Nepal, e-mail: ruchaghate@gmail.com 


\section{Contents}

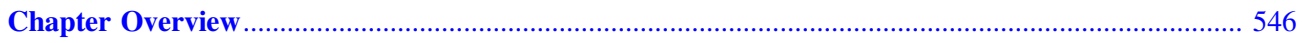

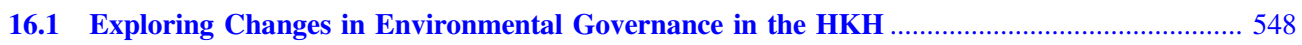

16.2 Predominance of National and Sub-national Policies and Institutions .................................... 550

16.2.1 Recent History of National and Sub-national HKH Environmental Policies

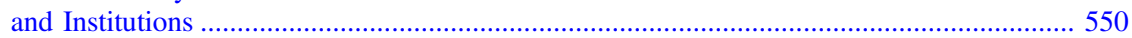

16.2.2 The Recent Shift Toward Decentralization and Community Participation............................ 552

16.2.3 The Emerging Focus on Multi-stakeholder Engagement .................................................... 553

16.2.4 The Role of Governance in Mainstreaming Climate Change in Development Plans .......... 554

16.2.5 Identifying Barriers to Policy Implementation .................................................................. 554

16.2.6 Gaps in Building Adequate and Responsive Institutions .................................................. 555

16.3 Empowering Local Institutions Through Decentralization and Devolution ............................. 556

16.3.1 The Status of Local Informal Institutions Under Increasing Decentralization .................... 557

16.3.2 The Effectiveness of Formal Community-Based and Decentralized Environmental Management.

16.3.3 The Insecurity of Local Resource Rights Despite Increasing Decentralization................... 559

16.3.4 Emerging Institutional Ambiguity in the Shift Toward Decentralization ............................ 559

16.3.5 The Potential and Limitations of Local Institutions in Confronting Social, Environmental,

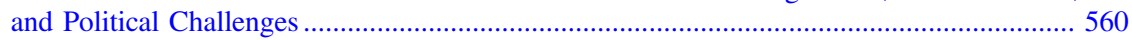

16.4 Regional Cooperation Is Key for Environmental Governance in the HKH ......................... 562

16.4.1 The Emerging Emphasis on Transboundary Cooperation for Regional Wellbeing ............. 562

16.4.2 The Growing Need for Formal Frameworks as a Foundation for Regional Cooperation ... 565

16.4.3 The Emergence of Knowledge-Sharing Platforms to Facilitate Regional Cooperation ....... 566

16.4.4 Emerging Mechanisms for Managing Conflicts and Equitably Distributing Benefits.......... 566

16.5 The Need for Strengthening Cross-Scalar Interfaces and Adaptive Governance ................... 567

16.5.1 Emerging Mechanisms for Managing Conflicts and Equitably Distributing Benefits.......... 568

16.5.2 The Imbalance Between Vertical and Horizontal Distribution Under Multilevel Governance.

16.5.3 The Emerging Role of Knowledge Interfaces in the Shift Towards Adaptive Governance

16.5.4 The Emerging Emphasis on Multilevel Learning for Inclusive Policies and Transformational Governance .

16.6 Opportunities for Improving Environmental Governance in the HKH 572

References 572

\section{Chapter Overview}

\section{Key Findings}

1. There are few existing regional policies and processes for environmental governance in the Hindu Kush Himalaya (HKH)—most are national and subnational. If this imbalance persists, it will undermine sustainable natural resource management in the region. Furthermore, it should be stressed, the implementation of existing policies and legislations in the $\mathrm{HKH}$ remains ineffective.
2. Environmental governance reforms in the HKH emphasize decentralization, often creating positive local outcomes-yet these local initiatives are not adequately supported through subnational and national governance systems. Successful local initiatives involve local communities, local governments and-increasingly-local and small-scale business groups.

3. HKH countries lack institutions to link upstream and downstream communities in river basins and mountain landscapes. Environmental institutions need to address the complex geography 
of the region. Collaboration is hampered by limited data and knowledge sharing, by weak local political representation at higher levels, and by insufficient attention to social equity and inclusion.

\section{Policy Messages}

1. Governments and environmental institutions in the HKH need to act now to strengthen the interface among science, policy, and practice. Urgent actions in this direction are needed to improve policymaking, regional development planning, and adaptive environmental governance in the face of growing climate change impacts and persistent livelihoods challenges.

2. Transboundary cooperation is crucial for improving environmental governance in the HKH. However, it is lacking mainly because the focus of intergovernmental initiatives has been on political and economic interests, rather than social and environmental wellbeing at the regional scale. Progress requires the establishment of formal, mutually agreeable frameworks for cooperation that are translated into action. HKH countries should build on ongoing collaboration initiatives to build and expand cooperation on complex transboundary environmental issues such as water basin management and energy security.

3. Environmental policy implementation in $\mathbf{H K H}$ countries will improve only if national governments recognize the multi-sectorial and cross-scalar nature of environmental governance. Implementation depends on the engagement of various stakeholders, including local communities. There is also a need for facilitating upstream and downstream interactions for improving landscape level governance. For this, governments need to create regulatory frameworks and local institutional arrangements to enable the expansion of successful initiatives to empower community action and inspire community-government partnerships. There is an opportunity to learn from the past four decades of decentralization and community based resource management policies and programs and upscale and institutionalize the successful initiatives across the region.
This chapter identifies four governance keys to the sustainable future of the $\mathrm{HKH}$ :

1. Institutional innovation-for landscape level governance, upstream-downstream linkages, and for translating policy goals into action;

2. Upscaling and institutionalizing decentralized and community based resource management practices;

3. Transboundary cooperation for managing connected landscapes; and

4. Science-policy-practice interface for decision making, learning and effective implementation of policies and programs.

The governance of environmental resources holds the key to the future of sustainable development in the Hindu Kush Himalaya (HKH). Environmental resources in the region are diverse and include forest, water, biodiversity, and agriculture. The governance of these resources involves a complex ensemble of policies, institutions, policy-making practices, and implementation procedures (well-established). More broadly, the term environmental governance denotes the ways in which both formal and informal institutions act to control and manage the environment in light of various social, cultural, economic, and ecological values. It also entails questions like who benefits and who loses, and finding ways to ensure equitable sharing of benefits, costs, and risks.

While disproportionate in their influence, national environmental policies and institutions are complex and still evolving in response to many challenges of HKH environmental governance. A number of state agencies have emerged in the HKH countries, but they face challenges to achieve coordination and linkages across different levels: local, sub-national, national, regional, and global (wellestablished). At present, environmental governance in the HKH remains distributed unevenly across these various levels, with limited mechanisms and processes in place to build linkages across scales. Much of the planning and decision making power rests with national and subnational authorities, while regional and local authorities have much less. This imbalance in the vertical distribution of governing power is often incompatible with sustainable natural resource management (well-established).

Institutional diversity in environmental governance is growing, creating opportunities for innovation. State agencies and local communities, too, have a long history in $\mathrm{HKH}$ environmental governance. And non-governmental organizations, private organizations, and knowledge communities have recently become more active. In general, the space for multi-actor engagement is now expanding across the region, but this opportunity still remains underutilised (established but incomplete). 
Environmental governance faces other challenges besides the dominance of national and subnational authorities. One is that environmental institutions have not yet fully adapted to the complex geography of the Hindu Kush Himalaya. As a result, the region lacks appropriate and context-specific institutions to link upstream and downstream communities in river basins (established but incomplete). Another institutional challenge is the sectoral fragmentation of environmental governance, which impedes coordination (well-established).

The HKH region has begun to see reforms in environmental governance, especially through decentralization and devolution. Many of these initiatives address new and recent concerns in the region - climate change, disaster risks, and threats to biodiversity. Other reforms have promoted shifts toward market mechanisms in resource governance, especially for the water, energy, and agriculture sectors (established but incomplete).

Although many of the reforms at the national and sub-national level aiming at decentralization and devolution have succeeded locally, they cannot have a more substantial impact without concurrent reforms in national and sub-national governance. These are needed to ensure an adequate institutional set up and linkages at various levels of governance. The reason is that local initiatives tend to prove limited when brought to scale. The limitations arise not only from poorly conceived policy frameworks, but from inadequate attention to inequalities of power and from fundamental deficits in accountability and representation. Unclear lines of authority and accountability often hinder effective devolution, and significant policy reforms are not translated into practice (established but incomplete).

Other failures of institutional effectiveness and implementation also persist. Cooperation among HKH country governments is hampered by limited cross-border knowledge sharing, as well as by recurrent geopolitical standoffs in the context of growing global significance of the region. Within the national level, governance systems characterize weak cross-scale political representation and insufficient attention to social equity and inclusion (established but incomplete). Another weakness is a continued disregard of scientific evidence which is itself limited in the context of HKH environmental systems. Although rich and abundant, local knowledge also remains underutilized in policy-making processes (established but incomplete).

Increasingly, a need is being recognized for a polycentric approach to $\mathrm{HKH}$ environmental resource governance: one that would emphasize new partnerships and cross-scale linkages with improved knowledge-sharing platforms for diverse stakeholders (established but incomplete). Also urgently needed are improved political articulations in the region that is undergoing rapid socioeconomic change and emerging geopolitical dynamics, and at the same time confronting serious environmental risks (established but incomplete).
While taking a broad view of environmental governance in the $\mathrm{HKH}$, this chapter specifically examines three major resource sectors in the region: forest, water, and rangeland. These are the most prominent resources capturing a large part of the environmental governance space in the region-for example, $60 \%$ of the $\mathrm{HKH}$ region is under rangeland and 12 major river systems originate from the Himalayas. It documents the current state of governance in these sectors and describes emerging trends in environmental policy and practice. It identifies both gaps and opportunities in policy-making, in regulatory arrangements and enforceability, and in the adaptability of environmental governance to rising climate change impacts. Its central claim is that managing the resources of the HKH sustainably will depend largely on the emergence of regional and innovative institutional arrangements - to foster intergovernmental dialogue, to further common policy initiatives, and to enable collaborative trans-border community practices.

\section{Environmental Governance and the Sustainable Development Goals}

Promote a mountain-specific agenda for achieving the SDGs through increased regional cooperation among and between mountain regions and nations.

It is increasingly being recognized that international cooperation is essential for global or regional environmental governance. In HKH region such cooperation needs to be based on sharing of scientifically collected information, developing comprehensive policies and accepting innovative practices leading to sustainable and mutual benefits. There is a need to revitalize the regional partnership in decision making institutions and processes by prioritizing the uniqueness of the HKH mountains and its people and ensuring their representation in higher platforms of decision-making. It is also important to recognize the need for allocating sufficient resources for maintaining mountain ecosystems, and at the same time develop incentive mechanisms to encourage private as well as collective efforts towards conservation and sustainable use.

\subsection{Exploring Changes in Environmental Governance in the HKH}

This chapter focuses on assessing environmental governance and highlighting key trends and practices in policymaking, institutional dynamics, and resource management practices at local, national, sub-national, and regional levels. In Chap. 2 
we have seen how environmental challenges cannot be addressed without strong and timely government interventions. It also elaborated on the consequences of poor environmental governance or a lack of it (see Sect. 2.3.3 for more details). The present chapter establishes a link between socioenvironmental change and the underlying structure of governance, which is itself changing over time. This link is important because, as we have seen in Chap. 4, researchers and practitioners consider poor governance as the third most important factor, after disasters and climate change, that poses the greatest threat to the prosperity of the region. The intention is not to make an exhaustive assessment of environmental governance in the $\mathrm{HKH}$, but to identify and present specific forms of evidence that demonstrate the current state of governance and emerging trends in environmental policy and practice. In doing so, we identify gaps and opportunities related to policy making, regulatory arrangements and enforceability, and the overall adaptability of the governance system in the face of growing climate change impact in the region. We recognize that the term "environment" is broad, comprising the totality of the natural system, and we focus on three specific resource sectors - forest, water, and rangeland - to highlight key trends and practices in governance.

We take a broad view of environmental governance as an ensemble of state policies, formal and informal institutions, and practices related to the control and management of the environment for a variety of economic, cultural, ecological, and social values. In essence, environmental governance involves defining and enacting rules related to the use, control, and management of environmental resources. Such rules emerge either inside the formal system of the state (such as regulatory arrangements) or under traditional and indigenous arrangements of resource control. Regulations are defined as legally binding rules formed by the state, including constitutions, statutes, common laws, and governmental regulations, which are externally enforced (Bacho 2005).

We also consider policy-making processes and stakeholder engagement as essential components of environmental governance. Policies are primarily seen as statements of intent to guide actions in both the short and long term. Institution is used to include organizations and entities that are involved in the process of translating or otherwise modifying policy and regulatory arrangements in the practice of governance. Policies and institutions are closely linked to practices. They determine who is eligible to make decisions, which actions are allowed, which rules will be used, what procedures will be followed, what information must be produced, what payoffs will be assigned to individuals, and how outcomes and processes will be monitored (Ostrom 1991). We cover both formal (statutory) and informal (traditional) institutions in environmental governance. Formal institutions are generally linked to official, governmental, or bureaucratic formalities and are usually legally defined. At the local level, institutions also include those based on social norms and rules that are not formally coded (Leach et al. 1999). They include traditional authorities, indigenous groups (chiefs, clan heads, family heads, and others), and organizations, as defined in local societal norms, values, and beliefs.

Overall, governance processes and practices are conceptualized as multi-scalar phenomena; thus, the assessment presented here covers local, sub-national, national, and regional levels (Fig. 16.1). The assessment is based on secondary data and literature review, capturing the latest research while drawing on policy literature, while also drawing on the longstanding research of the lead and contributing authors. The evidence presented is not drawn equally from all countries of the region but is instead based on the availability of published sources. We did not aim for a balanced representation of countries or sectors; rather, we focused on presenting the diversity of situations and trends in environmental governance. We have used case studies as illustrations, not for comparative analysis.

The chapter is organized by scale-national, local, and regional-followed by an analysis of cross-scale interactions and how practices across scales are either linked or remain disjointed. Following this Introduction, the next section focuses on environmental governance at the national and sub-national levels by presenting a broad review of the status of policy and institutions governing natural resources and analyses policy implementation at this level. We indicate how policies, regulations, and institutions are changing over time and highlight important gaps related to the lack of coherence, deficits in implementation, and tendency to ignore evidence in policy-making processes.

Thereafter, we assess local level environmental governance, focusing on community-level institutions and local government. As we demonstrate, decentralized and community-based approaches to environmental management have emerged as a global agenda for advancing sustainable development, and considering this shift in global policy debate, we provide an assessment of this phenomenon in the HKH. We assess the extent and trends of devolution and decentralization of power to communities or local governments, drawing on indicative evidence on the outcomes of this important policy change in terms of livelihood security and ecological sustainability. We show that ambiguous lines of authority, representation, and accountability too often hinder effective decentralization and devolution in practice. We also explore opportunities for the HKH countries to strengthen local governance systems for natural resource management, to empower communities, and to involve local governments and authorities.

This is followed by an assessment of regional-level cooperation in environmental governance in the HKH. We assess the evolving mechanisms and processes through 
Fig. 16.1 Conceptual framework for multidimensional governance

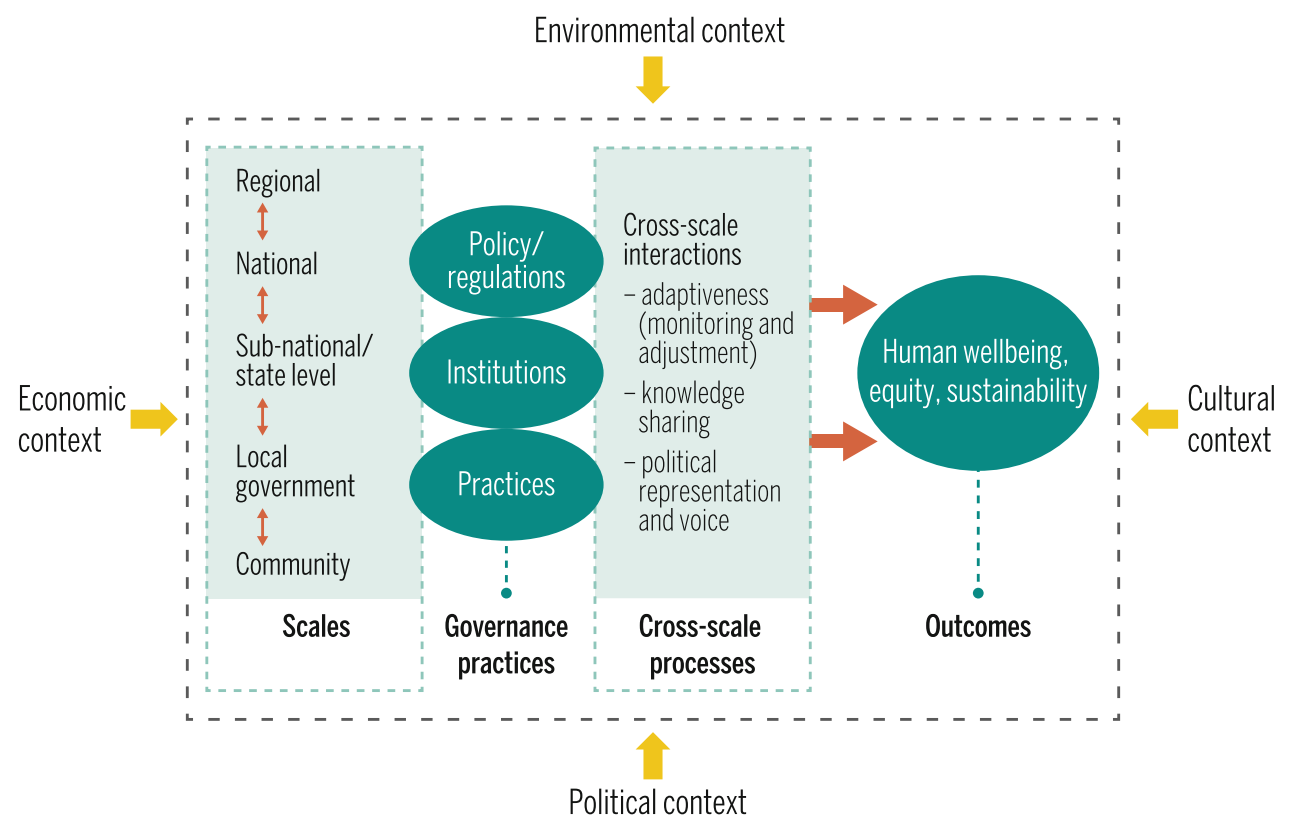

which $\mathrm{HKH}$ countries engage in regional cooperation, and then identify their promise and gaps. Highlighting the context of globalization and increasing interconnectedness among the HKH countries, we demonstrate that the prospect for regional environmental cooperation has increased. Lastly, the chapter presents a cross-scalar analysis of governance focusing on knowledge interfaces, vertical interaction, social inclusion, and adaptive governance systems. Here, we explore gaps and opportunities for linking local, national, and regional processes for better vertical cooperation using the lens of polycentric and adaptive governance. We demonstrate that although environmental governance in the $\mathrm{HKH}$ is a cross-scalar practice, deliberate attempts to foster cross-scale learning and adaptation are far from adequate. Finally, we summarize the situation of environmental governance and the opportunities presented for improvement.

Overall, the chapter provides a strategic assessment of environmental governance in the $\mathrm{HKH}$ and identifies opportunities for improved cross-scalar governance in the context of the growing need for tackling the twin challenges of ongoing climate change and socioeconomic transformation in the region.

\subsection{Predominance of National and Sub-national Policies and Institutions}

Although there is increasing acknowledgement of the $\mathrm{HKH}$ as a region of interconnected transboundary landscapes, governance and policy processes remain primarily at the level of individual countries. Despite being at different levels of economic development and diverse in their political, administrative, and legal setup (Chettri et al. 2008), all the countries in the region have formulated policies and legal instruments to safeguard the environment and foster sustainable utilization of natural resources (see Table 16.1). Environmental governance, in particular, has gained momentum under the increasing authority and role of central governments in policy making and development planning since the 1950s. ${ }^{1}$ From that point, and especially after the 1992 United Nations Conference on Environment and Development, countries started formulating policies concerning the environment and sustainable management of natural resources. The region has seen increasing policy reforms to regulate the environment and common pool resources (CPRs), particularly forests, rangelands, and water. Overall, there has been a gradual paradigm shift from a species- and habitat-focused approach to a participatory livelihood-based landscape approach to conservation policies and practices (Sharma et al. 2010).

\subsubsection{Recent History of National and Sub-national HKH Environmental Policies and Institutions}

Environmental policies and laws in the HKH countries initially evolved under central governments and were later expanded through donor support and NGO and community

\footnotetext{
${ }^{1}$ The first national Five-Year-Plans (FYPs) were implemented by India from 1951 to1956, China from 1953 to 1957 , Pakistan from 1955 to 1960, Afghanistan and Nepal from 1956 to 1961, Bhutan from 1961 to 1966, Bangladesh from 1973 to 1978, and Myanmar from 2011/12 to 2015/16.
} 
Table 16.1 Primary environmental and natural resource policies and laws in the HKH

\begin{tabular}{|c|c|c|c|c|}
\hline Countries & Environment (General) & Forest & Rangeland & Water \\
\hline \multirow[t]{2}{*}{ Afghanistan } & \multirow{2}{*}{$\begin{array}{l}\text { National Environmental } \\
\text { Protection Agency } \\
\text { (NEPA) 2005, Islamic } \\
\text { Republic of Afghanistan, } \\
\text { Environmental Law } 2007\end{array}$} & $\begin{array}{l}\text { Policy and Strategy for the } \\
\text { Forestry and Range } \\
\text { Management Sub-sectors } \\
2003\end{array}$ & \multirow[t]{2}{*}{ Rangeland Law 2012} & $\begin{array}{l}\text { Strategic Policy } \\
\text { Framework for the Water } \\
\text { Sector } 2006\end{array}$ \\
\hline & & Forest Law 2006 & & $\begin{array}{l}\text { Water Law of Afghanistan } \\
2009 \text { (revised from 1991) }\end{array}$ \\
\hline Bangladesh & $\begin{array}{l}\text { Bangladesh Environment } \\
\text { Conservation Act 2010; } \\
\text { National Environment } \\
\text { Policy 1992, and } \\
\text { Bangladesh } \\
\text { Environmental } \\
\text { Conservation Rules } 1997\end{array}$ & $\begin{array}{l}\text { Forest Act } 1927 \text { and } \\
\text { Amendment }\end{array}$ & N.A. & $\begin{array}{l}\text { Bangladesh Water Act } \\
2013\end{array}$ \\
\hline \multirow[t]{3}{*}{ Bhutan } & \multirow[t]{3}{*}{$\begin{array}{l}\text { National Environment } \\
\text { Protection Act } 2007\end{array}$} & $\begin{array}{l}\text { Forest and Nature } \\
\text { Conservation Act } 1995\end{array}$ & $\begin{array}{l}\text { Forest and Nature } \\
\text { Conservation Act } 1995\end{array}$ & Water Policy 2008 \\
\hline & & \multirow[t]{2}{*}{ Biodiversity Act 2003} & \multirow[t]{2}{*}{ Land Act of Bhutan 2007} & Water Act 2011 \\
\hline & & & & Water Regulations 2014 \\
\hline China & $\begin{array}{l}\text { Environmental Protection } \\
\text { Law 1989, revised 2014, } \\
\text { effective } 1 \text { January } 2015\end{array}$ & Forest Law 1998 & Rangeland Law 2003 & Water Law 1988 \\
\hline \multirow[t]{2}{*}{ India } & $\begin{array}{l}\text { Environment Protection } \\
\text { Act } 1986\end{array}$ & \multirow[t]{2}{*}{$\begin{array}{l}\text { Forest (Conservation) Act } \\
1980\end{array}$} & \multirow[t]{2}{*}{ N.A. } & \multirow{2}{*}{$\begin{array}{l}\text { The Water (Prevention } \\
\text { and Pollution Control) Act } \\
1974\end{array}$} \\
\hline & $\begin{array}{l}\text { National Environment } \\
\text { Policy } 2006\end{array}$ & & & \\
\hline Nepal & $\begin{array}{l}\text { Environment Protection } \\
\text { Act } 1997\end{array}$ & $\begin{array}{l}\text { Forest Act } 1993 \\
\text { Forest Regulations } 1995\end{array}$ & Rangeland Policy 2012 & Water Resources Act 1992 \\
\hline \multirow[t]{4}{*}{ Myanmar } & \multirow{4}{*}{$\begin{array}{l}\text { Environmental } \\
\text { Conservation Law } 2012\end{array}$} & \multirow{4}{*}{$\begin{array}{l}\text { Forest Law } 1992 \\
\text { Forest Policy } 1995 \\
\text { Forest Rules } 1995\end{array}$} & \multirow[t]{4}{*}{ N.A. } & Canal Act 1905 \\
\hline & & & & Water Power Act 1927 \\
\hline & & & & Groundwater Act 1930 \\
\hline & & & & $\begin{array}{l}\text { Conservation of Water } \\
\text { Resources Law } 2006\end{array}$ \\
\hline \multirow[t]{3}{*}{ Pakistan } & $\begin{array}{l}\text { Environment Protection } \\
\text { Act } 1997\end{array}$ & \multirow[t]{3}{*}{$\begin{array}{l}\text { National Forest Policy } \\
2015\end{array}$} & \multirow[t]{3}{*}{$\begin{array}{l}\text { Khyber Pakhtunkhwa } \\
\text { Rangeland Policy } 2014\end{array}$} & $\begin{array}{l}\text { Draft National Water } \\
\text { Policy } 2005\end{array}$ \\
\hline & \multirow[t]{2}{*}{$\begin{array}{l}\text { National Environment } \\
\text { Policy } 2005\end{array}$} & & & $\begin{array}{l}\text { National Sanitation Policy } \\
2006\end{array}$ \\
\hline & & & & $\begin{array}{l}\text { National Drinking Water } \\
\text { Policy } 2009\end{array}$ \\
\hline
\end{tabular}

movements. All HKH countries have a long history of community dependence on and engagement in the management of natural resources, whereby the natural resources were controlled, appropriated, and managed through locally evolved norms, indigenous practices, and institutions (Fisher 1989; Shrestha 2016) (see Sect. 16.3). With the increasing involvement of the state in modern times, natural resources have increasingly been governed through policies and laws made centrally.

In some of the HKH countries, the emergence of national environmental policies and the expansion of institutions have been spurred in part by democratic changes. In Bangladesh, Bhutan, India, Nepal, Pakistan, and, recently, Myanmar, elected parliaments provide policy directions and make laws. In Afghanistan, presidential decrees and laws passed by the national parliament continue to be influenced by tribal or customary laws (Khan 2015). In China, the National People's Congress (NPC) and its Standing Committee are mandated bodies that approve policy directives and enact laws. Today, all HKH countries have a plethora of policies and legal instruments (see Table 16.1). Forest regulations were the first among the environmental laws to be made in the region. In India, the Forest Act 1865 that marked the beginning of state control of forest was formulated under the pre-partition British regime, primarily for the colonial interest in using the forests for industry (Baginski and Blaikie 2007; Muhammed 
et al. 2008). In Nepal, forests were nationalized in 1957, prior to which many areas were converted to farmland and timber extracted for export (Gautam et al. 2004). In Bhutan, state control of forests came with the enactment and revision of the Forest and Nature Conservation Act of 1969 (later revised in 1995) and the Land Act of 1979, which reduced the status of local communities from "owners" to "proprietors" (Dorji et al. 2006). All countries accord high priority to conservation of forests and biodiversity; 39\% of the region's estimated $3,441,719 \mathrm{~km}^{2}$ is designated as protected area (Chettri et al. 2008)

\section{Box 16.1 Factors affecting the governance of natural resources in the Hindu Kush Himalaya}

1. The remoteness of mountain communities and their distance from decision-making centres reduces coordination of formal and informal institutions.

2. Physical fragility has a high impact on natural resources, necessitating a mechanism for quick response, which local institutions may lack.

3. Being highly dependent on nature for subsistence, mountain communities do not respond well to restrictions on resource use, which are difficult to impose and monitor.

4. Ethnic diversity, resulting in the heterogeneity of cultures, traditions, and practices, can hinder consensus in decision making.

5. Lack of clear property rights over high-value niche products in mountains may lead to over-exploitation.

6. The transboundary quality of natural resources places limits on the effective monitoring, patrolling, and use of sanctions across borders.

7. The governance of resources that are transboundary in nature is limited by conflicting policies and institutions among the countries sharing the resources.

Alongside policies and regulations, the national institutional landscape has also grown over the past several decades. The institutional setup for regulation and implementation of the environmental policies and laws is centralized, with coordination authority vested in ministries, commissions, and departments. Water resources are regulated by councils or commissions in Afghanistan, Bhutan, and Nepal, and by ministries in China, India, Pakistan, and Myanmar. Forest resources in the region are regulated primarily by forest departments at the central, state, and provincial levels. There are no institutions solely dedicated to regulating rangelands. Except for China, which has a separate law, rangelands in most HKH countries come under the purview of the forest department.

\subsubsection{The Recent Shift Toward Decentralization and Community Participation}

Although there was an initial transfer of authority and control of natural resources, especially forests and rangelands, from traditional communities to central agencies, environmental and natural resource policies are now moving toward decentralization and devolution to communities of power and rights over natural resource access and management (Agrawal 2001). The HKH countries are progressively embracing good governance based on the principles of decentralization, gender-sensitive participation, and equitable access to resources. Governments are increasingly finding ways to promote local management of natural resources, especially forest resources, while ensuring central government control and authority.

According to Sharma et al. (2010), along with the integration of many global conventions, there has been a gradual paradigm shift in conservation policies and practices encompassing acceptance of local communities as an integral part of national conservation initiatives. This shift has been triggered in part by the acknowledgement of continued environmental degradation when resources were exclusively under centralized government authority. Forests and rangelands in all HKH countries were initially brought under state control through exploitative forest policies and laws primarily to meet state interests in exploiting forest to generate revenue and support industry (Muhammed et al. 2008). Responding to deterioration in the condition of forests, and acknowledging the increasing cost of managing forest without community involvement, governments have implemented processes, sometimes through donor support, that allow local community access and engagement in forest and rangeland conservation and management. This has come about in the form of social forestry in Bangladesh, community forestry in Nepal and Bhutan, joint forest management in Pakistan, and the Scheduled Tribes and Other Traditional Forest Dwellers (Recognition of Forest Rights) Act, 2006 in India (Baginski and Blaikie 2007). The move towards decentralization of authority under community forestry programmes is reported to have contributed immensely to the economic advancement of isolated rural communities in Nepal (Dahal and Chapagain 2005) and Bhutan (Namgyel 2005) (discussed in more detail in Sect. 16.3). In Bangladesh, for example, six major social forestry projects have together generated a total of $80.55 \mathrm{~m}$ man/days of work 
opportunities and raised some 97,584 ha of plantations between 1980 and 1999. FD office records suggest that Taka 700 million worth of products were harvested from social forestry plantations in about a decade, and Taka 5000 crore worth of assets generated (Chowdhury 2001; Mowla 2001; Khan et al. 2004).

The shift toward decentralized management is also apparent in the water sector. Water use and management in all HKH countries is governed specifically by water policies and acts initiated at different times that provide for state control over all sources of water (Table 16.1). But in recent times, governments have been taking the initiative to move toward decentralized management of water resources through the establishment and empowerment of river basin committees and water users' associations for the purpose of equitable benefit sharing. Since the first half of the 1990s, several programmatic efforts (notably, the Third and Fourth Fisheries Projects, Management of Aquatic Resources through Community Husbandry-MACH) have been made to engage local communities in water co-management in Bangladesh with varying degrees of success. Despite many limitations, these efforts have refocused attention on community engagement and documented the benefits arising from such engagements (USAID 2010; Halder and Thompson 2006).

The situation for rangelands is different. While China has a separate policy for rangelands, Nepal finalized its rangeland policy only in 2015. In the case of Pakistan, rangelands are under the jurisdiction of provincial governments, and the province of Khybar Pakhtunkhwa adopted a rangeland policy in 2014. In the rest of the HKH countries, rangeland laws are integrated into the provisions under forest and conservation laws.

While the trend toward decentralized management is welcome (see Box 16.1 for examples), it is now widely agreed that local institutions in the HKH countries lack coordination with the state and with policies at the national level. This lack of cross-cutting institutional coordination weakens the environmental governance processes within the countries of the region.

\section{Box 16.2 Forests as a source of income}

The majority of the countries in the HKH have evolved from being poverty-indifferent to being poverty-responsive, with policies that now take into account the needs of the poor by clearly defining their rights to resources. For example, Nepal's community forestry regulations allow community forest user groups to freely fix prices, market, and make profits, with $25 \%$ of the income from forestry invested for forest development (Ojha et al. 2009). From 2007 onward, it was made mandatory to invest $35 \%$ of income generated from community forests in pro-poor programmes and to include women in the key posts of the user group executive committees (Pokharel et al. 2012). In Bhutan, the Gross National Happiness Commission adopts a budget allocation formula that allows for resources to be allocated on the basis of population and poverty incidence. In India, policy and legislation provide quotas for employment in the government and other sectors (Venkateswarlu 2013). Further, the recent grant of authority to highland nomadic communities for the harvest of the medicinal Cordyceps sinensis has transformed their poverty and hardship to prosperity (Namgyel 2005).

\subsubsection{The Emerging Focus on Multi-stakeholder Engagement}

In global environmental governance reforms, stakeholder participation is widely acknowledged as an important aspect of policy making, development planning, and implementation of sustainable natural resource management (Larson and Soto 2008). This trend finds resonance in environmental governance in the $\mathrm{HKH}$, and can be described as emerging hybrid modes of governance across the state-market-community. There are three distinct levels with two interfaces (Khan and Hossain 2006):

1. international and regional level, where the stakeholders are primarily international governing bodies, donor agencies, international NGOs, and governments;

2. national level, where the players are government and national-level NGOs, together with the private sector; and

3. grass-roots level, where the main actors are community-based organizations (CBOs), local NGOs, local governments, and development agencies.

Each of these levels has distinct functions and forms of partnership among the three types of social institutions, i.e., the state, private sector, and civil society. Coordination and collaboration between these operational levels occurs across two interfaces: national-international and national-grassroots (Khan and Hossain 2006).

In the $\mathrm{HKH}$, the public sector, communities, and private sector are emerging as partners, though not equal, in the governance of resources. For example, in Bhutan, sectoral policies are subjected to vigorous stakeholder consultations and a policy screening tool to ensure that the proposed policy upholds the values and principles of Gross National Happiness (GNH). Gross National Happiness is the 
fundamental development philosophy providing the framework for sectoral policies and initiatives. Essentially, it calls for a balanced and integrated approach to socioeconomic development, preservation of the environmental and cultural heritage, and promotion of good governance. In India, the media, judiciary, and civil society are playing increasingly vocal roles in advocating for mountain environments, and all development projects that affect natural resources require clearance from local panchayat institutions (these local institutions are for conflict resolution, rural development, and natural resource governance in many South Asian countries, including India, Bangladesh, Nepal, and Pakistan) (Ghosh 2008). Communities and advocacy groups also engage in public consultations over new government policies. In Nepal, stakeholder engagement has been expanding with increasing recognition of the private sector (Timsina and Gotame 2014).

\subsubsection{The Role of Governance in Mainstreaming Climate Change in Development Plans}

All countries in the HKH have heeded the United Nations call for mainstreaming environment into development planning and decision making in order to achieve the dual purpose of poverty reduction and environmental sustainability. A key aspect of mainstreaming environment is to orient governance, institutions, and political systems aimed at improving the environment in ways that also benefit the poor and reduce vulnerability to the effects of climate change (UNDP-UNEP 2009). Mainstreaming of environment and climate change through projects has begun in the region through the adoption of the Sustainable Development Goals and the ratification of the 2015 Paris Agreement and with support from international donors (UNFCCC 2015). However, the policies often adopt a linear process with discrete steps of policy formulation and implementation, without considering the governance challenges that exist (Friend et al. 2013). As a result, the process is often driven by global imperatives rather than through national-level political forums, as reported in the case of climate policy development in Nepal (Nightingale 2016; Ojha et al. 2016). While adaptation remains a priority, the HKH countries are also pursuing mitigation policies to reduce carbon emissions. Bangladesh, China, India, and Nepal were among the first globally to ratify the Paris Agreement.

Experiences in mainstreaming climate change into development plans reveal implementation challenges due to the disconnect between various tiers of governance. In Nepal, projects—often donor supported — have had a limited effect on the ground due to the highly centralized design and implementation process, engagement of only government stakeholders, limited time frames, and fragmented activities. Regmi and Star (2015) analysed how climate change is mainstreamed in Nepal in two case studies. The findings suggest that one of the governance challenges to mainstreaming of community-based adaptation into the development process is the gap in implementation approaches. Regmi and Star's findings show that bottom-up approaches, for example the Local Adaptation Plan of Action (LAPA), were successful in mobilizing local community groups and increasing their awareness. However, they failed to influence the government institutions, which resulted in a lack of support and continuity from the centre, highlighting the critical disconnect between policy and practice.

\subsubsection{Identifying Barriers to Policy Implementation}

The policies and laws for the management of natural resources in the $\mathrm{HKH}$ are fairly comprehensive including provisions for decentralization and the need for mainstreaming wider environmental concerns in development planning. Table 16.1 summarizes the major policies and legislation formulated for environmental protection in general, and forests, water, and rangeland, in particular. All eight countries have an overarching environmental protection act. The forest related acts are the oldest, and rangeland related acts and policies the most recent (2015 in Nepal). There have been conflicting views on having integrated policy and legislation for all-natural resources versus having separate policies and acts with a focus on specific resources.

The experience suggests that mainstreaming at policy level has been successful, but that gaps between policy formulation and implementation are common in all the $\mathrm{HKH}$ countries. A number of studies, as cited below, have noted barriers and challenges in implementing policies and legislation, including the lack of clarity and appropriateness of policies and the inadequacy of the regulatory and institutional arrangements. In China, the Environmental Protection Law of 2014, though perceived as the most progressive and stringent, was considered by some to be inadequate in terms of the overriding power of other laws such as the water law, as well as other factors, including the fragmented and overlapping structure of environmental governance; shielding of the government from lawsuits by citizens, civil groups, and NGOs for breach of environmental standards; and lack of capacity and conflicts of interest that may impede implementation (Zhang and Cao 2015). In Pakistan, policies were described as rhetoric, theoretical, and politics-driven, and were often associated with change of government (Shabaz et al. 2007). In Bangladesh, the policy response to forestry sector development was described as loaded with rhetoric (Khan and Harriss-White 2012). In 
countries like China and India, where mountain areas constitute only a fraction of the entire country, overall national policies do not adequately address mountain-specific needs (Sharma and Chettri 2005), and this disregard of mountain specificities reduces options for communities, rendering them vulnerable to environmental and economic distresses (Jodha 2005). In Nepal, one of the key factors thought to be hindering successful implementation of pro-poor community forestry was that both projects and government line agencies had historically been compartmentalized and were restricted in the range of services they could offer to user groups (Pokharel et al. 2007).

Another aspect of the policy implementation gap is the donor dependence of the developing economies in the region. Countries like Afghanistan, Bangladesh, Bhutan, Myanmar, Nepal, and Pakistan are still dependent on external assistance for their development needs. Donors are assisting these countries in developing exhaustive policies and legal instruments, but they are not adequately followed through for a number of reasons related to relevance and inadequate institutional, human, and financial capacity.

\subsubsection{Gaps in Building Adequate and Responsive Institutions}

Administrative agencies form the fundamental institutional setting for policy implementation and thereby influence outcomes (Maynard-Moody and Herbert 1989). Inappropriate institutional settings and lack of strategies and actions for proper implementation can be as much a cause for policy-related failures as inappropriately contextualized policies (Peters 2015; Zittoun 2015). Faulty implementation can also be the result of the inadequacy of the administrative agencies represented by the public institutions, or their ineffectiveness in delivering public services and implementing programmes. Institutional weaknesses have been identified as the direct result of bureaucratic political weaknesses and non-accountability in South Asian states like Afghanistan, Bangladesh, India, Nepal, and Pakistan (Robbins 2000; Wirsing 2007; Barnes and Laerhoven 2014; Fleischman 2014).

Limited institutional capacity has affected the natural resource sector in many HKH countries, and this in turn has compromised the implementation of policies and the provision of timely and useful feedback to policy development. In Nepal, the functions of government agencies, particularly sectoral organizations such as the district forest offices (DFOs) and the district livestock service offices (DLSOs), have often been influenced by the availability of programme funds. While institutions supporting two related programmes - community forestry and leasehold forestry-lacked coordination to enhance overall effectiveness (Bhattarai et al.
2007; Ojha 2014). In Bangladesh, several managerial and technical problems have hindered policy and programme implementation in forest management. The problems include lack of skilled manpower, minimal capital investment, and lack of relevant expertise for translating international forest policies into national forestry plans at the national and regional levels (Muhammed et al. 2008). In Afghanistan, centralized state institutions have co-existed uneasily with fragmented, decentralized traditional society since attempts at state-building began (See Box 16.2).

While rangeland institutions are well-developed in countries like China and Bhutan, they have only recently started to take shape in India and Nepal. In Nepal, the policies and governance necessary for promoting rangeland management have only been developed recently (Ministry of Livestock Development 2017). Previously, public services and technical support were either unavailable or inaccessible to local herders in the mountainous rangelands of northern Nepal, and research, development, and provision of extension services were lacking (Dong et al. 2009).

Similarly, institutions for water management in many parts of the region lack the capacity to design and deliver effective management functions. For example, Pakistan lacks investment in storage capacity, water-use efficiency, and sustainable management of surface water and groundwater resources to avoid problems of soil salinization and waterlogging (Watto and Mugera 2016). In Afghanistan, institutions do not have access to suitable or sufficient information and data for planning, and there is a shortage of efficient institutions, organizational capabilities of staff, and effective rules and regulations regarding water use, in part due to persistent wars. In Bhutan, lack of human resources and capacity remains a major constraint on effective inter-agency coordination for implementing integrated water resource management required by the Water Act. Mahmoodi (2008) found that only $30 \%$ of the country's potential water resources were being used, while the rest remained inaccessible. The current status of policy and institutions for upstream-downstream linkages is also limited in the HKH, although the importance of these linkages is increasingly recognized in recent research on transboundary water governance (Pigram 2000; Nepal et al. 2014; Rasul 2014; Shrestha and Ghate 2016).

\section{Box 16.3 Changing institutional structure due to conflicts}

For centuries, tribal and religious leaders in Afghanistan have created "microsocieties", which are related to central and other powers on the basis of negotiation and patronage. However, the years of conflict and civil war have changed the nature of politics both at the local level and between the local and national levels. 
The co-existence broke down as power became highly decentralized and factional leaders, operating in relatively distinct geographic areas, organized loose alliances to gain control of, or resist, the centre. Hierarchies of commanders, so-called "warlords", came to dominate large areas, linked in some areas to tribal structures. Structures of power are dynamic, however, and evidence from Afghanistan suggests that they continue to change, and the complex ways that power holders interact with the state institutions continue to be modified (Lister 2007).

The war in Afghanistan has also caused disintegration of the traditional arrangements of rangeland institutions and led to the lack of an enabling policy environment for sustainable rangeland use. Further, the lack of coherent legislation on land rights has generated conflicts between nomads and sedentary farmers due to conflicts of interest between winter grazing and crop cultivation. In some cases, conflicts have arisen between government authorities and local communities, since government-owned land was not distinguished from publicly-owned land, and common resources were taken away from communities by those in power (Ali and Shaoliang 2013).

The lack of institutional connectivity in the region has also hindered the ability of nation states to respond to crises. These constraints severely affected the relief and rehabilitation programmes after the Kedarnath disaster in the Uttarakhand Himalaya in June 2013, in which several thousand people died and the livelihoods and assets of a large proportion of the regional population were devastated (Tiwari and Joshi 2015). At present, some HKH countries are renewing their approach toward local government structures; for example, in Afghanistan they are linking village institutions, government ministries, and international donors (Noelle-Karimi 2006).

\subsection{Empowering Local Institutions Through Decentralization and Devolution}

In practice, environmental governance in the $\mathrm{HKH}$ is a profoundly local phenomenon, involving local communities, local governments, and increasingly local and small-scale business groups. Over the centuries, a variety of community-based natural resource management systems evolved in the region, based on traditional norms and indigenous institutions (Denholm 1991; Gilmour 1990; Farooquee et al. 2004; Sharma et al. 2006; Kreutzmann 2012). In Nepal, Farmer Managed Irrigation Systems
(FMIS) are known to exist going back centuries, and these continue to irrigate almost $70 \%$ of farmland in the country. (For more details, see Chap. 8.) However, since the 1950s, almost all the HKH countries have seen increased state engagement in policy formulation, enactment, and enforcement of legislation and implementation of state-sponsored programmes (Blaikie and Sadeque 2000). The era of direct state control over environmental resources led to a crisis of environmental degradation in the late 1980s (Ives and Messerli 1989), prompting national governments to adopt policies for participatory management, joint management, and community management, particularly for forest resources (Hobley 1996). Alongside the age-old tradition of community-based environmental management systems, all eight countries in the region have undertaken formal decentralization and devolution reforms, especially after 1990, transferring some power of governance to local communities and elected local governments (Baginski and Blaikie 2007; Pasakhala et al. 2017).

Globally, the move toward devolution and decentralization has been driven by multiple forces, including the loss of legitimacy and/or credibility of the centralized state (Bardhan 2002). This has led to demands for deregulation and an increased role for market players (Mohan 1996), escalating concerns about poverty reduction (Crook 2003), increasing awareness about the need for environmental conservation (Agrawal 2001), and the growing consensus that local stakeholder participation is required to achieve sustainability goals, which implies a need to improve governance through community involvement, engagement, and ownership (Fung and Wright 2001; Ribot 2003, 2007).

In the HKH, governments in collaboration with donors have invested heavily in strengthening local and subnational systems and developing new institutions, often reviving the indigenous institutions. Both customary and formal community management institutions, "facilitated" by state and development agencies, are important elements in the local governance of environmental resources, despite the diverse historical trajectories of environmental governance across the region (Mosse 1997; Agrawal and Gibson 1999; Blaikie 2006). For example, Nepal has a strongly decentralized community forestry system which blends traditional institutions and state-sponsored decentralization reform (Gilmour and Fisher 1991; Ojha 2014). On the other hand, published literature indicates that the efforts of establishing a strong centralized state have not been complemented by sufficient attention to local government at the provincial and district level. As a result, governance at the local level is very complex and confused in Afghanistan. The Indian Himalaya have a local government-centric forest management system which engages local people while retaining control within the government (Hobley 1996; Agrawal and Yadama 1997; Sivaramakrishnan 1999), and the Chinese Himalaya have also seen 
increasing trends towards decentralization, which is akin to de-concentration (Larson and Ribot 2004). In contrast, in Pakistan, the authority of the forest department has barely been decentralized, despite the adoption of a participatory or joint forest management strategy (Shahbaz et al. 2007).

The degree of decentralization also varies across the resource sectors within a country. For example, in contrast to forest and biodiversity management, the governance of water resources remains predominantly a national and subnational issue in most HKH countries. On the other hand, rangeland (which covers $60 \%$ of the entire $\mathrm{HKH}$ ) is primarily under community management even when formal rights are retained by the government (Sharma et al. 2007). While these examples suggest a common trend in transferring power from higher to lower levels of governance, there is no coherent body of evidence from the region to suggest that decentralization always has a positive outcome for people and the environment (Jütting et al. 2004). Rather, the impact varies in line with the geographic and political diversity in and within the individual countries.

Many of the decentralization and devolution policies are sponsored by aid agencies. International support has been crucial in providing resources for decentralization projects and, in particular, in promoting mechanisms to enhance gender equality and social inclusion. Nevertheless, donor influence in decentralized governance has not always produced sustainable change and innovation (Guthman 1997; Sarin 2001, cited in Sarkar 2008; Rangan 1996; Nautiyal 2011). In Bangladesh, the imposition of a generic co-management "model" has caused local-level problems in negotiating popular acceptance of the programme and long-term institutional sustainability. In Pakistan, decentralization and collaborative governance agendas are driven by international agencies and the national administration, causing tensions with more local-level forest departments in the north of the country (Ali and Nyborg 2010).

Furthermore, the effectiveness of local institutions is shaped by external factors (Ojha et al. 2016a). For example, van panchayats in Uttarakhand in India are facing tremendous demographic and economic pressure, which is undermining the effectiveness of these institutions (Sarkar 2008). On the other hand, it is yet to be ascertained if the Biodiversity Management Committees (BMC) in the state have as much acceptability among communities as van panchayats or gram panchayats that have statutory mandate similar to BMC. The increasing professionalization of resource governance is leading to further democratic deficits. Policies become stronger in terms of technical considerations but lack the flexibility required for successful implementation in real life situations. Consequently, stakeholders often find themselves in a situation where state policies do not address their interests, leading to increased conflicts over the proper governance of local-level resources (Nightingale 2005).
Therefore, community-based natural resource management is not only about community-level decision makers; it also requires inputs from government actors and agencies, and sometimes the involvement of market actors where forest products can be exchanged for cash (Agrawal and Verma 2017).

\subsubsection{The Status of Local Informal Institutions Under Increasing Decentralization}

Growing socio-anthropological research clearly states that communities possess unique local information which distant state agencies generally do not possess, and which may help solve complex environmental problems (Ostrom 1990, 2010). Community-based institutions are vital in the enforcement of shared norms of behaviour and in resolving conflicts (North 1990; Ghate and Chaturvedi 2016). Moreover, the formal involvement of community members is likely to enable a more equitable allocation of benefits from environmental resources because community members have a better understanding of their needs and can pressure state officials to distribute benefits more equitably (Agrawal and Lemos 2007). Chapter 8 indicates how traditional institutions are marked with gender inequality when it comes to access to water.

In Afghanistan, the new Water Sector Policy has adopted principles for implementing integrated water resource management (IWRM) and decentralizing activities gradually to the river-basin and sub-basin levels. According to Mahmoodi (2008), programmes have been developed to achieve the strategic goals outlined in the policy in terms of institutional development, capacity building, poverty alleviation, modernizing irrigation systems, prevention of water loss, water resource development, expanding rural water supply, improving sanitation system, and river bank protection. The government now prioritizes water and power development through IWRM, and water has been heralded as the means to achieve other economic and developmental goals.

Box 16.4 Community Forestry in Nepal: An example of successful community-based environmental management

Nepal's community forestry has a formal history of more than 40 years; it was first triggered by the Himalayan degradation perceived in the 1970s (Ives and Messerli 1989). With more than one-third of the population involved, and over a dozen international and bilateral agencies supporting the process through at least four different regimes, community forestry is now deemed successful in terms of scale of activity, length of experience, diversity of local management 
regimes, and richness in facilitative experience in devising ways to achieve both poverty reduction and conservation goals (Acharya 2002; Ojha et al. 2009). However, gender mainstreaming in forest governance and policy remains far from desirable (for details, see Chap. 8).

\subsubsection{The Effectiveness of Formal Community-Based and Decentralized Environmental Management}

Assessing the effectiveness of decentralized programmes in the HKH is difficult, as indicated by the challenges outlined in the previous section. However, some key insights emerge, even if the picture is mixed. The most notable case of community-based resource management is Nepal's community forestry, which started in the late 70s in the hills of Nepal (Gilmour and Fisher 1991). This programme is considered successful in (a) bringing local communities back into the management process by recognizing their rights over forests; (b) fostering institutional innovation based on community or participatory forest management mechanisms; (c) transforming the rules of resource management to favour forest sustainability; (d) developing a self-sustaining system by broadening the range of actors to undertake diverse functions; and (e) balancing discursive and practical aspects of the democratic movement (Pokharel et al. 2007). These categories are useful in terms of assessing community forestry in other parts of the $\mathrm{HKH}$, but the institutional and policy diversity across the region makes direct comparisons difficult.

Empirical evidence suggests Nepal's community forestry has been a success in terms of enhancing the flow of forest products, improving livelihood opportunities for forest-dependent people (Pokharel and Nurse 2004; Subedi 2006; Chapagain and Banjade 2009), transforming institutions and social capital (Nightingale 2005, 2006; Bhattarai et al. 2009), and improving the ecological condition of forests (Gautam et al. 2002). The success of community forestry in Nepal served as a major impetus for Bhutan, Myanmar, and Pakistan to initiate community forestry. However, the effectiveness of community forestry in these new contexts has been mixed, in part due to differences in the decentralized policies.

Efforts at the decentralized management of other resources also suffer from institutional diversity, overlaps with traditional systems, and lack of integration with the government departments that control the same resource under centralized mechanisms. The Indian Himalaya have a wide range of local governance systems across forest, water, and rangelands, with marked differences between the eastern and western sections. They include van panchayats in Uttarakhand and Himachal Pradesh, traditional forest management institutions in North East India, and joint forest management across India. These programmes have been only partially successful, and have been criticized in particular for failing to protect the rights of tribal groups. The Scheduled Tribes and Other Traditional Forest Dwellers (Recognition of Forest Rights) Act 2006 was introduced in an attempt to decentralize forest resources to these groups, but its implementation has been resisted by government departments at various levels (Sarker 2011; Kumar et al. 2015). Since the 1990 s, several efforts have been made in the water management sector in India, focusing on the role of local communities (Agarwal and Narain 2002). These efforts involve forming user groups called water users' associations (WUAs) for irrigation systems in an attempt to ensure more effective distribution of limited irrigation water.

Nepal has developed water governance mechanisms at the local level, but at the same time, the governance of watersheds and rivers is not systematic; moreover, it is managed mostly centrally. At the local level, most places have systems of kulos, or canals, for irrigation, and in some cases for drinking water, that are collectively dug and mutually maintained. In many places, kulo systems stretch for dozens of kilometres. Many of these systems are very old, while others are new innovations spurred on by development projects and government provision of drinking water systems. Kulos tend to have "invisible" management institutions in that they lack formal written rules or regular meetings. Rather, they have established mechanisms for getting all user households to contribute labour for maintenance of the canals, and meetings only take place when conflicts arise or the system breaks down.

In Pakistan, a decentralized local government system was introduced in 2001 and most of the provincial departments were handed over to local (district) governments. Forest departments, however, were among the few departments that were not devolved, even though participatory or joint forest management and social forestry had already been initiated in Khyber Pakhtunkhwa (KPK) (Shabaz et al. 2007). A study based in Baltistan and Kargil suggests that interventions by government and non-government agencies alter water-users' institutional arrangements, and that such interventions should build on, rather than erode, existing arrangements (Hill 2014).

In Myanmar, the Forest Department issued the Community Forestry Instructions (CFIs) in 1995 and has been encouraging the development of community forestry in collaboration with international donor organizations. According to the data for 2015 from the Forest Department Statistics Division (available at its website), a total of 2,023 community forest user groups with 54,041 members have established 113,016 ha (279,268 acres) of community forest plantations. Although the Forest Department is trying to 
revise the existing 1995 CFI in consultation with multi-stakeholders, the degree of devolution to local communities is limited. Decentralization was mandated by the 2008 Constitution of Myanmar (GOM 2008), but has been met by challenges at both the local and central level. Myanmar is a highly centralized country with a history of subnational conflicts and relatively weak local institutions and communities, all of which has hampered the decentralization effort (Nixon et al. 2013).

In Bangladesh, since the early 2000s, there has been an organized attempt toward the consolidation of decentralized "community-focused" governance, especially in the forest and wetlands sectors. These programmes have mainly been dispensed under the broad rubric of "co-management" targeting the country's protected areas (PAs). The adoption of this co-management approach is seen as an attempt to influence the governance process toward a transformation from the conventional custodian system to a more participatory management regime. While an encouraging trend, problems in implementation abound (Jashimuddin and Inoue 2012).

\subsubsection{The Insecurity of Local Resource Rights Despite Increasing Decentralization}

Resource rights and tenure have been identified as a critical aspect of decentralized natural resource management that is needed to ensure that users feel ownership in the long-term sustainability of their resources (Acharya et al. 2008; Paudel et al. 2009; Larson 2010, 2011; Larson et al. 2013). Yet regularizing property and tenure rights is never straightforward. Decentralization often ignores traditional institutions and crafts new ones, leading to longer-term conflicts both within and between communities. At present, a variety of tenurial arrangements are evolving across the region with varying degrees of effectiveness.

In Pakistan, forest management at the local institutional level is represented by the joint forest management committees (JFMCs); while at the provincial level, the Forest Department of Khyber Pakhtunkhwa gives the power to divisional forest officers to assign state forest to a JFMC. The stated function of the JFMCs is to protect and manage their piece of forest. However, there is a huge gap between the de jure and de facto status. The de jure status of JFMCs is democratic, but many research studies have argued that most JFMCs have been created exclusively for timber harvesting rather than forest management and/or protection (Shahbaz 2009).

In China, there is a high degree of devolution underway, as power is shifted from the state to village collectives and individual ownership of forests (Xu 2010). However, despite a significant decentralization of forest rights, farmers feel that their property rights are still insecure (Qin et al. 2011).
Likewise, the arrangements for payment for ecosystem services in China are notable for governance innovation in terms of public-private partnership, but confusion still persists about the role of the private sector (Zhen and Zhang 2011).

In India, institutional arrangements for environmental services have often been made without an adequate understanding of the local politics of negotiation, leading to a number of conflicts and institutional breakdown. In North East India, very few people within the local communities actually own the resources; thus, any new attempts at tenure reform encounter strong resistance. In western India, local-level water users' associations (WUAs) were hijacked by the local elite, who were able to evade accountability because of their location in village networks (Narain 2003). Within the larger policy discourse on irrigation reform, WUAs came to be seen as some kind of panacea for the ills of the irrigation sector, but there was little effort to integrate these measures with other aspects of irrigation reform, such as pricing, cost recovery, or improvement in water supplies. Thus, WUA formation remained something of a piecemeal strategy carried out at the persuasion of donors and funders, with little reflection on what changes were being sought at the field level.

In Pakistan, the conservation focus in decentralized forest management has led to only limited benefit for livelihoods from participatory forestry, partly because there is still limited devolution of power and a failure to address pre-existing structures such as the traditional systems of riwaj and jirga, which exclude women and marginalized people (Shahbaz et al. 2011).

\subsubsection{Emerging Institutional Ambiguity in the Shift Toward Decentralization}

Despite the adoption by the HKH countries of a broad policy vision of decentralized environmental governance, the implementation of this policy is characterized by contradictions and lack of coherence, a situation which at times is akin to "giving with one hand while taking with the other" (Capistrano 2012: 210). The evidence shows that in practice, the decentralization processes across the HKH are not smooth as a result of many challenges, including deep-rooted centralized governance, sub-national conflicts, and the limited capacity of local institutions (Nixon et al. 2013).

In China, confusion over the direction of policy has led to either inappropriate policies or poor implementation of existing policies - as, for example, in the case of rangeland policy (Gongbuzeren et al. 2015). In Bhutan, central agencies continue to dominate control and allocation of natural resources. Provision of forest resources such as timber and sand for rural community needs are regulated by the Department of Forest and Park Services through its 
divisional offices at the district level. Urban demands for timber and sand are regulated and rationed through the government-owned Natural Resource Development Corporation Limited (NRDCL). In Myanmar, policy has shifted toward decentralization and devolution, but as in most places, government departments still compete in actual implementation, undermining policy goals. For example, Section 17(a) of the National Constitution states that "the executive power of the Union is shared among the Pyidaungsu, Regions, and States; Self-Administrative power shall be shared between Self-Administered Areas as prescribed by this Constitution". In terms of forest resource management, the Community Forestry Institution (1995) allows localities to establish community forestry in areas adjacent to or currently relied on by the local communities. However, the Forest Department does not allow local communities to implement community forestry within protected areas, and it grants permission only in protected public forests and reserve forests. Thus, in terms of power sharing, local communities are not empowered to manage their forest resources, even though they were granted the right to forest tenure 30 years ago.

In the highlands of Pakistan, forest departments were not decentralized during the 2001 decentralization reforms, although the district governments were given the mandate to take care of the interests of local communities who depend on forest resources for their livelihoods. These ambiguous lines of authority led to communication gaps and eventually poor interactions between the stakeholders in forest management interventions (Shabaz et al. 2007; Watto et al. 2010).

In Nepal, there is continued confusion between the roles of communities and local government in the local-level governance of natural resources, as the Forest Act 1993 and Local Self Governance Act 1999 created authority overlaps among forest officers, local governments, and community groups. Six different regimes of decentralized and/or collaborative governance have emerged, partly because of the need to accommodate the diverse and contested interests of communities, state agencies, and other players. Due to unclear laws and overlapping functions, the central government continues in its role of providing public services like health, education, and drinking water through its line agencies. Such functions overlap to a considerable extent between different levels of government and are ambiguous in terms of which level is responsible for regulation, financing, and implementation (Gautam and Pokhrel 2011).

In Bhutan, there is a tendency to restrict legislative rights through bylaws or directives that undermine the original objectives of decentralized policies (Chhetri et al. 2009). For example, the Bhutan Observer reported research results in November 2012 which showed that contributions from community forestry account for only $0.3 \%$ of household income because of the restrictions on the use of forest resources.

In Afghanistan, efforts to rehabilitate depleted watersheds are constrained by poor security, uncertain land tenure and use rights, limited local environmental management capacity and focus on agriculture to meet immediate local economic needs (Groninger 2012). Environmental management is embroiled in cultural, transnational, military, and developmental worldviews and institutions that leave little room for the perspectives of local people.

\subsubsection{The Potential and Limitations of Local Institutions in Confronting Social, Environmental, and Political Challenges}

Evaluating the outcomes of devolution is complicated by the kinds of diversity in policy and practice and the challenges outlined above. Nevertheless, several achievements can be identified which provide examples of good practice.

Nepal's community forestry has been particularly strong in attempting to address the well-known problems of elite capture and exclusion of women and marginalized people. In terms of gender and equity, many gains have been made. Innovative practices include the following (Acharya 2004; Hobley and Jha 2012):

- Use of quotas on management boards and within organizations and user groups to try to ensure the inclusion of socially marginalized people. In Nepal, as more widely in the HKH, this most often means quotas for women, Dalits, and indigenous people. While these provisions may not safeguard the rights of marginalized people, they do provide legal and normative grounds for such people to demand a greater stake in decision-making processes.

- The promotion of marginalized community members into leadership roles within organizations. This is sometimes done by quotas and sometimes promoted by donors as a desirable practice. We see more of this practice within community-level institutions than at other levels.

- The formation of community-level management groups that are restricted to women or Dalit or indigenous members. These groups are intended to help overcome some of the broad discrimination that all members of these groups feel. Groups composed of marginalized people often find it difficult to retain control over their resources, however, and face greater challenges in negotiating with powerful government actors (Nightingale 2006).

Alongside these optimistic trends, growing evidence indicates that the success of Nepal community forestry is mixed in terms of both livelihoods (Malla 2000, 2001; 
Acharya 2002, 2004; Thoms 2008; Shrestha 2016) and ecological systems (Acharya 2004). Multiple processes are shaping these issues: agricultural intensification in localities close to urban areas (Raut et al. 2010), increased market demand for timber and forest products without effective evolution of local institutions (Pandit and Thapa 2004), outmigration, and climate change. Indeed, community forestry is not free from issues related to distributional injustice, recentralization, and ineffective use of forest resources under community management (Ojha 2006; Thoms 2008; Shrestha 2012; Nightingale 2016). In particular, local-level institutions face challenges related to elite capture and what we might call "participatory exclusion", whereby marginalized people might be given a place within a group and even a voice, but in practice they are unable to influence group decisions (Nightingale 2005, 2006; Ojha 2006; Shrestha 2012).

In other parts of the HKH, similar attempts have been made to address social inequalities and tenure insecurity for marginalized people, again with mixed results. The achievements of the community forestry programmes in Bangladesh over the past three decades include efforts to include women and disadvantaged groups, reforestation on marginal lands, and improvements to degraded forest and community lands (Jashimuddin and Inoue 2012). Recent research suggests that (1) despite its limitations, co-management as a concept has gradually taken root in Bangladesh; (2) the degree and level of active community participation remains low and limited, and there is a clear weakness in orienting local communities to the key legal and policy issues related to protected area governance in the country; (3) the key drivers of success in co-management are poverty alleviation through livelihood creation, capacity building, equity in benefit sharing, recognition of tenure rights, and shared governance that involves the devolution of power to transparent participatory local institutions; and (4) in many instances, local site-specific needs and demands have not been adequately addressed.

In Myanmar, the establishment of community forests supports a wide range of benefits for local communities in terms of their basic needs (poles/posts, fuelwood, other non-timber forest products) and ecosystem services (recreation, mitigating climate change, conserving natural water springs for drinking water and other uses), as well as developing social capital at the community level (Tint et al. 2011). The Forest Law 1992 (GOM 1992), Forest Policy 1995 (GOM 1995a), and CFI 1995 (GOM 1995b) barely recognize gender and equity issues in managing and utilizing natural resources, and the policy emphasis is still on revenue/economic benefit and managing environmental sustainability. More recently, however, the Land Use Policy (2016) has recognized the rights and benefits of local communities, particularly for women, marginalized people, and ethnic minorities.
Analysis of the forests of Himachal Pradesh suggests that the tension represented by the co-governance management regime contrasted with the indigenous system is associated with a worsening condition of the forests (Agrawal and Chhatre 2006).

Overall, despite its challenges, decentralization has helped to legitimize local-level institutions across the HKH, both nationally and internationally. The formal processes of decentralizing environmental resource management are underpinned by changes in the constitutional, legal, policy, and procedural arrangements in all the countries. However, decentralization faces many challenges in terms of acceptance at different levels of governance within countries and the ability of established institutions to confront social, environmental, and political change.

In recent years, pre-existing ("traditional") institutions have either been replaced or modified through the introduction of formal institutions. For example, in Afghanistan, despite strong community-based arrangements, attempts have been made by national and international organizations to modernize the irrigation system using centralized approaches. While the indigenous technology did not allow the measurement of water consumption, the externally-funded projects for modernization of water management which can do that are seen as potentially violating the local water governance systems and causing conflict (Wegerich 2009). In northern China, participatory water users' associations (WUAs) are replacing traditional irrigation water management systems in order to promote economically and ecologically beneficial water management options (Zhang et al. 2013). In Bhutan, the enactment of forest laws has led to nationalization of forests and loss of traditional rights over forest, resulting in diminished incentives to protect (Dorji et al. 2006) and non-compliant behavior at the local level (Webb and Dorji 2007). The shifting (devolution) of roles from formal to informal institutions is best exemplified in the forestry sector in Nepal. Forest policy and regulations related to community forestry allow the government to hand over the whole or parts of a national forest area to the local community (see Box 16.3).

Studies show that traditional institutions have been crucial in resource conservation and local livelihoods, but problems of inequity and elite domination also abound. In many parts of Khyber Pakhtunkhwa in northwestern Pakistan, decisions regarding access to forest resources and other socioeconomic aspects are rooted in sociocultural mechanisms called riwaj or customary law and jirga (assembly of tribal elders) (Rome 2005). These institutions have been criticized by civil society groups for failing to safeguard the rights of women and other marginalized community members (Shahbaz and Ali 2003). In Nepal, in situations where the formal mandate for newly decentralized institutions has lapsed, local elites tend to fill the 
vacuum of control, most often to the detriment of the rights of women and marginalized resource users (Nightingale 2006; Nightingale and Sharma 2014). It is therefore crucial that both the potential and the limitations of local-level institutions are considered when promoting various forms of decentralization.

\subsection{Regional Cooperation Is Key for Environmental Governance in the $\mathrm{HKH}$}

Regional or transnational cooperation has emerged as a key form of global environmental governance, as opportunities for international cooperation and transboundary environmental management expand rapidly. Although the Himalaya is probably one of the most politically complex and ecologically fragile regions in the world (Ives 2012), it is also an example of the potential for provision of a range of environmental systems and services (Grumbine and Pandit 2013; Blaikie and Muldavin 2004). With the rise of the Chinese and Indian economies - located to the north and south of the mountain chain - the region has also become a geopolitical and political economic centre of global importance (Wirsing 2013; Zhang 2016), simultaneously posing both ecological and political opportunities and challenges (Goldstein et al. 2006). The increasing level of upstream-downstream interrelationships, such as those pertaining to transboundary water systems, also demands greater international cooperation in the region. As a result, achieving sustainable natural resource management in the $\mathrm{HKH}$ will require a reasonable degree of cooperation among national governments and communities across borders (Karki and Gurung 2012), as well as large-scale investments for prosperity in the future (Chap. 4). The need for regional collaboration is most vividly demonstrated by the case of water management.

Water "ignores political boundaries, fluctuates in both space and time, and has multiple and conflicting demands on its use", and its international law is poorly developed, contradictory, and unenforceable (Wolf and Hamner 2000: 123). With ten river systems flowing across the boundaries of the $\mathrm{HKH}$, bilateral and multilateral treaties and agreements for the allocation and distribution of water will be indispensable in governing the ecosystems at a regional scale. Several such agreements have been signed over the past five decades (Table 16.2). Some bilateral programmes (for example, the Koshi River Watershed Management Programme between Nepal and India) have been implemented since the 1980s and 1990 s with the aim of regulating the water supply and minimizing flooding. Afghanistan and Pakistan are in the process of reaching a similar water-sharing agreement for the Kunar River in the Kabul Basin (Vick 2014). Others, such as the Koshi River Agreement, the Gandak River Water Sharing
Agreement, and the Mahakali River Agreement between Nepal and India (Uprety and Salman 2011), the Ganges Water Treaty between India and Bangladesh (Brichieri-Colombi and Bradnock 2003), and the Indus River Water Treaty between India and Pakistan (Sahni 2006) aim primarily at ensuring the generation and sharing of power, and are often considered to lack fair, comprehensive, and equitable arrangements for resource use and allocation (Mustafa 2010; Uprety and Salman 2011; Butler 2016). Formal cooperation between China and India on transboundary water management remains limited (Rahaman and Varis 2009).

\subsubsection{The Emerging Emphasis on Transboundary Cooperation for Regional Wellbeing}

The practices of cooperation among the HKH countries are being driven increasingly by economic interests or political bargaining. The economic interests of the larger economies are competing for the extraction of natural resources, at times leading to a deterioration in the livelihoods and ecological integrity of smaller countries and communities. For example, upstream communities are being displaced in the process of construction of large-scale river dams to serve downstream populations (Blaikie and Muldavin 2004). The cross-border power trade has been growing and is one of the main contested issues, especially from the perspective of smaller countries (Crow and Singh 2000; Rest 2012). India has established the power trading companies specifically to develop and trade hydropower in the region (Karki and Vaidhya 2009). However, power trading agreements are not promoted through regional cooperation; rather, they are dealt with primarily at the bilateral level. The rationale is that the huge energy market in India can provide a source of income to countries such as Nepal and Bhutan and eventually promote environmental and conservation efforts (Biswas 2011). In most cases of transboundary cooperation, however, the regional economic powers such as China and India are often unable to reach agreements with the smaller countries (which in fact hold the larger section of the $\mathrm{HKH}$ ) that consider the wider social, cultural, and environmental interests of the smaller countries and the upstream communities (Blaikie and Muldavin 2004; Mustafa 2010).

Subnational-level collaborations along the borders are becoming effective, especially in dealing with issues related to transborder wildlife movements, grazing management, soil and water management, and maintaining ecological hot spots along the transboundary rivers. Even though these practices are ad hoc and irregular, they are a good example of how transboundary natural resource management could be implemented by mobilizing local authorities and subnational landscapes. These practices are common in areas with 
Table 16.2 Transboundary rivers in the HKH and related water treaties

\begin{tabular}{|c|c|c|c|}
\hline $\begin{array}{l}\text { Transboundary river } \\
\text { (Riparian countries) }\end{array}$ & $\begin{array}{l}\text { Treaties, agreements, and } \\
\text { institutions }\end{array}$ & $\begin{array}{l}\text { Nature of water sharing and use } \\
\text { as per treaty }\end{array}$ & Outcomes \\
\hline \multirow{2}{*}{$\begin{array}{l}\text { Mahakali [1] } \\
\text { (Nepal and India) }\end{array}$} & 1996 Treaty of Mahakali & \multirow[b]{2}{*}{$\begin{array}{l}\text { Guided by principles of } \\
\text { equality, mutual benefit, and no } \\
\text { harm to either party; equal } \\
\text { number of representatives from } \\
\text { both parties; equal partnership } \\
\text { to define obligations and } \\
\text { corresponding rights and duties } \\
\text { regarding water use, water } \\
\text { distribution, hydroelectricity, } \\
\text { irrigation, and flood control }\end{array}$} & \multirow[b]{2}{*}{$\begin{array}{l}\text { Arbitration tribunal dedicated to } \\
\text { resolving differences arising } \\
\text { under the Treaty; equal } \\
\text { representation of national } \\
\text { arbitrators with a third neutral } \\
\text { arbitrator presiding over the } \\
\text { tribunal (as written in Treaty } \\
\text { agreement); provision for } \\
\text { planning, surveying, } \\
\text { development, and operation of } \\
\text { any work on the tributaries of } \\
\text { the Mahakali river to be carried } \\
\text { out independently by either } \\
\text { party in its own territory }\end{array}$} \\
\hline & Mahakali River Commission & & \\
\hline \multirow[t]{2}{*}{$\begin{array}{l}\text { Koshi [2] } \\
\text { (Nepal and India) }\end{array}$} & $\begin{array}{l}\text { The } 1954 \text { Agreement on the } \\
\text { Koshi Project (revised in 1996) }\end{array}$ & \multirow[b]{2}{*}{$\begin{array}{l}\text { Flood control; irrigation; } \\
\text { generation of hydroelectricity } \\
\text { and prevention of erosion in } \\
\text { Nepal areas on the right side of } \\
\text { the river, upstream of the } \\
\text { barrage; surveys and } \\
\text { investigations necessary for } \\
\text { proper design, construction, } \\
\text { and maintenance of the barrage } \\
\text { and connected works; } \\
\text { navigation and fishing rights } \\
\text { reserved by Nepal }\end{array}$} & \multirow[b]{2}{*}{$\begin{array}{l}\text { Disputes or differences resolved } \\
\text { through arbitration in which } \\
\text { arbitrators are nominated from } \\
\text { each side within } 90 \text { days of } \\
\text { delivery of notice of dispute } \\
\text { arising from either party, and } \\
\text { the arbitrators' decision is } \\
\text { binding; if the arbitrators } \\
\text { disagree, both parties appoint } \\
\text { an umpire whose decision is } \\
\text { final and binding }\end{array}$} \\
\hline & $\begin{array}{l}\text { Indo-Nepal Koshi Project } \\
\text { Commission acting as the } \\
\text { coordination committee for the } \\
\text { Koshi Project }\end{array}$ & & \\
\hline $\begin{array}{l}\text { Gandaki [3] } \\
\text { (Nepal and India) }\end{array}$ & $\begin{array}{l}\text { Gandak River Treaty of } 1959 \\
\text { followed by the Agreement of } \\
\text { Gandak Irrigation and Power } \\
\text { Project } 1975\end{array}$ & $\begin{array}{l}\text { Irrigation and hydropower } \\
\text { development in both countries; } \\
\text { investigation and surveys; } \\
\text { communication }\end{array}$ & No assessments yet \\
\hline \multirow[t]{2}{*}{$\begin{array}{l}\text { Teesta and other water } \\
\text { resources [4] } \\
\text { (Bangladesh and India) }\end{array}$} & $\begin{array}{l}\text { Indo-Bangladesh Treaty of } \\
\text { Friendship, Cooperation, and } \\
\text { Peace; 25-year treaty signed in } \\
\text { 1972; also known as } \\
\text { Indira-Mujib Treaty }\end{array}$ & \multirow{2}{*}{$\begin{array}{l}\text { JRC addresses issues related to } \\
\text { sharing water of common } \\
\text { rivers; transmission of } \\
\text { flood-related data from India to } \\
\text { Bangladesh; construction and } \\
\text { repair of embankment and bank } \\
\text { protection work along } \\
\text { common/border rivers }\end{array}$} & \multirow{2}{*}{$\begin{array}{l}\text { The Indo-Bangladesh Treaty of } \\
1972 \text { was not renewed in 1997, } \\
\text { as both riparian countries } \\
\text { declined renegotiation; India's } \\
\text { role was seen as excessively } \\
\text { imposing and Bangladesh's } \\
\text { share was deemed unequal; } \\
\text { disputes over water resources at } \\
\text { Farakka Barrage, and India's } \\
\text { perceived delay in withdrawing } \\
\text { troops added to the contention; } \\
\text { other political externalities }\end{array}$} \\
\hline & $\begin{array}{l}\text { The Joint Rivers Commission } \\
\text { (JRC) of } 1972 \text { established by } \\
\text { the Government of Bangladesh, } \\
\text { Ministry of Water Resources }\end{array}$ & & \\
\hline $\begin{array}{l}\text { Ganga-Brahmaputra-Meghna } \\
\text { [5] } \\
\text { (Bhutan and India) }\end{array}$ & $\begin{array}{l}\text { Chukka Project of circa } 1980, \\
\text { based solely on generating } \\
\text { hydropower from the Wanchu } \\
\text { Cascade at Chukka }\end{array}$ & No assessments yet & $\begin{array}{l}\text { Project deemed highly } \\
\text { successful; covered its cost by } \\
1993 \text { and increased capacity to } \\
370 \text { MW; provided impetus for } \\
\text { Bhutan's industrialization and } \\
\text { commercial development; } \\
\text { Bhutan moved from country } \\
\text { with the lowest per capita } \\
\text { income in South Asia during } \\
\text { the 1960s to the highest in the } \\
\text { Ganga-Brahmaputra-Meghna } \\
\text { region (includes Bangladesh, } \\
\text { Bhutan, India, Nepal, and } \\
\text { Pakistan), with foreseeable } \\
\text { stipulated earnings of more than } \\
\text { USD100 million per annum } \\
\text { with similar hydropower } \\
\text { projects Kuri Chu, Chukka II, } \\
\text { and Chukka III by } 2015\end{array}$ \\
\hline
\end{tabular}


Table 16.2 (continued)

\begin{tabular}{|c|c|c|c|}
\hline $\begin{array}{l}\text { Transboundary river } \\
\text { (Riparian countries) }\end{array}$ & $\begin{array}{l}\text { Treaties, agreements, and } \\
\text { institutions }\end{array}$ & $\begin{array}{l}\text { Nature of water sharing and use } \\
\text { as per treaty }\end{array}$ & Outcomes \\
\hline $\begin{array}{l}\text { Brahmaputra/Yalu Zangbu [6] } \\
\text { (China and India) }\end{array}$ & $\begin{array}{l}\text { MOU on hydrological data } \\
\text { sharing on the } \\
\text { Brahmaputra/Yalu Zangbu } \\
\text { River signed in } 2001 \text {, renewed } \\
\text { in } 2008 \text { and } 2013\end{array}$ & $\begin{array}{l}\text { Data and information sharing } \\
\text { on water level, discharge, and } \\
\text { rainfall every year }\end{array}$ & No assessments yet \\
\hline $\begin{array}{l}\text { Sutlej/Langquin Zangbu [7] } \\
\text { (China and India) }\end{array}$ & $\begin{array}{l}\text { No treaty as such; China agreed } \\
\text { to provide hydrological } \\
\text { information }\end{array}$ & $\begin{array}{l}\text { Information for flood control, } \\
\text { data sharing, and transmission }\end{array}$ & No assessments yet \\
\hline $\begin{array}{l}\text { Indo-China river-basins [8] } \\
\text { (China and India) }\end{array}$ & $\begin{array}{l}\text { Expert-level mechanism } \\
\text { formed in } 2006 \text { in which expert } \\
\text { group, made up of } \\
\text { representatives from both sides, } \\
\text { discusses interaction and } \\
\text { cooperation on provision of } \\
\text { flood season hydrological data, } \\
\text { emergency management, and } \\
\text { other issues on an annual basis }\end{array}$ & $\begin{array}{l}\text { Data sharing for flood control, } \\
\text { emergency management, and } \\
\text { other issues }\end{array}$ & No assessments yet \\
\hline $\begin{array}{l}\text { Indus [9] } \\
\text { (India and Pakistan; } \\
\text { Afghanistan and China are } \\
\text { upper riparian but not } \\
\text { members) }\end{array}$ & Indus Treaty of 1960 & $\begin{array}{l}\text { Pakistan claimed historical } \\
\text { rights and "equitable } \\
\text { apportionment" and India } \\
\text { claimed prior use and } \\
\text { preservation of status quo }\end{array}$ & $\begin{array}{l}\text { Disputes over how water will } \\
\text { be utilized and allocated were } \\
\text { later resolved through the } \\
\text { World Bank's involvement as a } \\
\text { mediator and arbitrator } \\
\text { financier of the partition } \\
\text { projects, which meant that the } \\
\text { final treaty was planned and } \\
\text { formulated by the Bank; } \\
\text { involvement of only a few } \\
\text { riparian countries may have led } \\
\text { to a less effective alliance; only } \\
\text { treaty of its kind to arise } \\
\text { post-partition in the Indian } \\
\text { subcontinent; the partition of } \\
\text { the Indus happened after } \\
\text { attempts at basin-wide } \\
\text { development and planning } \\
\text { failed; the treaty is still } \\
\text { considered a sub-optimal } \\
\text { solution to the management of } \\
\text { the Indus }\end{array}$ \\
\hline \multirow[t]{2}{*}{$\begin{array}{l}\text { Mekong [10] } \\
\text { (Thailand, Laos, Viet Nam, } \\
\text { Cambodia, China, Myanmar) }\end{array}$} & \multirow[t]{2}{*}{$\begin{array}{l}\text { The Mekong Committee } \\
\text { (MC) established in 1957; in } \\
1995 \text { the Mekong River } \\
\text { Commission (MRC) was } \\
\text { developed }\end{array}$} & \multirow[t]{2}{*}{$\begin{array}{l}\text { Hydropower, flood control, } \\
\text { fishing, irrigation, navigation, } \\
\text { and water supply }\end{array}$} & $\begin{array}{l}\text { Dam building a threat to lower } \\
\text { riparian countries; growing } \\
\text { conflict between upper and } \\
\text { lower riparian; legal and } \\
\text { political differences and } \\
\text { complexities in } \\
\text { implementation; involvement of } \\
\text { only a few riparian countries } \\
\text { led to a less effective alliance }\end{array}$ \\
\hline & & & $\begin{array}{l}\text { Data collection; coordination; } \\
\text { training programmes; planning } \\
\text { studies; management of water } \\
\text { for developmental uses; } \\
\text { ministerial-level reach in the } \\
\text { Commission for political } \\
\text { influence }\end{array}$ \\
\hline
\end{tabular}

Source Shrestha, A. and Ghate, R., 2016

[1] Stiftung (2001); [2, 3] GON (1975); [4, 9] Kliot et al. (2001); [5] Biswas (2011); [6-8] Cumming (2011); [10] Guttman (2003) 
open and semi-open border controls, such as those between Nepal and India, Nepal and China, Bhutan and India, and Bangladesh and India.

In recent years, donor-funded transboundary projects have become a new category of regional-level collaboration for the management of natural resources and ecological systems in the HKH. For example, the International Centre for Integrated Mountain Development (ICIMOD) is facilitating the Kailash Sacred Landscape Conservation and Development Initiative (KSLCDI) as a collaborative effort between China, India, and Nepal, with financial support from the German Federal Ministry for Economic Cooperation and Development (BMZ) and the United Kingdom Department for International Development (DFID). The Initiative is a collaborative programme for transboundary cooperation and ecosystem management across a culturally and ecologically important landscape within the three countries. ICIMOD has planned or is implementing a number of other transboundary landscape and trans-Himalayan transect programmes in the $\mathrm{HKH}$, including in the Mt. Everest region (Sherpa et al. 2003), the Hkakabo Razi Complex (Guangwei 2002), and the Kanchenjunga Landscape (Chettri et al. 2008), which have shown that regional cooperation for biodiversity conservation and management is both feasible and necessary (Chhetri et al. 2009; Schild and Sharma 2011).

These donor-initiated collaborative programmes have developed useful methodologies for transboundary governance of a particular landscape, promoted operational-level networks, and provided opportunities for regional-level policy discussions. However, there is a long way to go in crafting a systematic and comprehensive framework so that the countries in the HKH can collaborate and implement regional-level activities that collectively promote the Himalayas as a sustainable eco-region.

Trans-community collaborations based on informal understanding, historic cultural ties, traditional trade practices, mutual cattle herding systems, and watershed connectivity are common. They are based on organic transboundary mechanisms for governing natural resources at the local level. For example, communities across the border between Nepal and China, Nepal and India, and Bhutan and India have collaborated historically on pasture land management, promotion of forest diversity, regulation of wells for water, religious protection of ecological landscapes, and mutual development of livelihood opportunities (Ning et al. 2013, 2016). Chapter 5 elaborates why cooperation among regional member countries is essential for dealing with cross-border wildlife trade and human-wildlife conflict. These historical and indigenous trans-community practices can provide a basis for a larger eco-Himalaya-level collaboration and regional policy framework that ensures community participation and addresses both livelihoods and national-level economic interests.
Developing vertical and horizontal linkages and collaboration among intergovernmental, national, and local institutions is essential in fostering transboundary partnerships and cooperation. The existing regional-level institutions have generated some ecological knowledge and project-based partnerships. However, one of the main reasons for the lack of positive environmental outcomes has been that the focus of intergovernmental initiatives and bilateral treaties has been on economic interests and profitability rather than social and environmental wellbeing at a regional scale. To quote from Pasakhala et al. (2017), "in the $\mathrm{HKH}$, classical transboundary cooperation will grow organically, triggered by common management objectives and common livelihoods opportunities, to constructively forge conservation and development across scales, for instance, common value chains and common branding of products, responsible and cultural heritage tourism."

\subsubsection{The Growing Need for Formal Frameworks as a Foundation for Regional Cooperation}

While transboundary landscape management initiatives are emerging and the age-old practices of trans-community collaboration at the community level are advancing, these collaborations are not directly endorsed or informed by formal treaties between the participating nations, and the small-scale transboundary activities are not strongly linked to the larger processes of cooperation emerging at the regional level. One of the more important regional collaborative platforms with potential for improving collaborative governance of natural resources is the South Asian Association for Regional Cooperation (SAARC). SAARC has identified environmental restoration, disaster risk reduction, and climate change as priority areas for regional cooperation, and the SAARC countries have collectively agreed that sustainable development and environmental management are the most significant issues in the region (Dorji 2007; Wyes and Lewandowski 2012). The SAARC Development Goals include conservation of land, forest, biodiversity, and water resources; reduction of natural disasters; and climate change mitigation and adaptation (Wyes and Lewandowski 2012). Other networks like Bhutan, Bangladesh, India, and Nepal (BBIN) and The Bay of Bengal Initiative for Multi-Sectoral Technical and Economic Cooperation (BIMSTEC), which includes Bangladesh, India, Myanmar, Sri Lanka, Thailand, Bhutan, and Nepal, may not provide viable institutional modalities, as these are mainly driven by regional geopolitical interests and exclude China and Pakistan, for example. Similarly, networks that support on-the-ground institutional mechanisms for natural resource governance, like the South Asia Wildlife Enforcement Network (SAWEN) and South Asia Watch on 
Trade, Economics, and Environment (SAWTEE), have a specific but limited agenda. What is needed for a sustainable $\mathrm{HKH}$ is a platform shared by all eight countries as an eco-region and at that scale.

The SAARC Comprehensive Framework on Disaster Management and Disaster Prevention is another initiative on regional-level collaborative governance. The SAARC Centre for Disaster Management and Preparedness, SAARC Coastal Zone Management Centre, and SAARC Meteorological Research Centre are some examples that can provide instruction on how regional institutional mechanisms could be established for natural resource management. However, notwithstanding the enormous potential, SAARC has remained a weak and ineffective regional body and has not been able to develop trust and mutual understanding on landscape-level collaboration and governance. The non-binding nature of SAARC-level agreements, lack of trust among the member countries, and growing geopolitical tension in the region have all turned this regional institution into a formality rather than a commitment for regional collaboration (Tiwari and Joshi 2015).

Scholars argue that the lack of horizontal and vertical linkages among diverse institutions and actors is hindering efforts towards collaborative natural resource governance in the HKH (Kohler et al. 2012). There is still a lack of serious recognition by the national-level actors of the need for regional-level cooperation on natural resource governance (Tiwari and Joshi 2015). Efforts from intergovernmental institutions such as SAARC and ICIMOD are non-binding and have been found insufficient to truly generate concrete collaborative commitments and programmes (Wyes and Lewandowski 2012). The potential for horizontal linkages among regional institutions such as ICIMOD and SAARC remains underutilized, as the processes are driven by different actors, use approaches that are either too informal or too rigid, or remain limited to academic debates without engaging the national decision makers.

\subsubsection{The Emergence of Knowledge-Sharing Platforms to Facilitate Regional Cooperation}

HKH countries have varied and extremely rich experiences in relation to environmental management, often with a potential for sharing and adoption across borders. However, existing practices remain isolated inside individual countries and are not much shared across the region (Tiwari and Joshi 2015). Community-level institutions such as community forestry in Nepal (Ojha 2014; Paudel 2016) and joint forest management in India (Bhattacharya et al. 2010) have been effective as bottom-up institutions in promoting social and ecological wellbeing. They present an opportunity for communities, local governments, small businesses, and policy makers to learn through comparative and cross-sharing of experience and learning. Policy makers could also learn how local practices can inform national policy development processes.

Developing trans-community collaboration among local actors and fostering vertical linkages between the regional HKH-level and the local practices of resource governance across multiple HKH countries could provide an opportunity for multi-scalar governance of the HKH as a comprehensive eco-region (see next section for a more detailed discussion of multi-scalar governance). However, such linkages are currently confined to national-level actors and have varying degrees of effectiveness, while linkages within countries still tend to be top-down (Malla 2000; Ojha 2014). There is a tremendous opportunity for recognition and encouragement of knowledge-sharing platforms at a regional level to pool insights and experience from across the region.

The various processes and mechanisms related to knowledge-sharing at the regional level provide important insights into how such sharing can be strengthened. The work of ICIMOD demonstrates the case for an intergovernmental mechanism to implement transboundary action research projects and generate and share knowledge among both state and non-state actors in the region. However, regional processes led by civil society tend to be confined to the South Asian belt of the Himalaya, mainly Bangladesh, India, and Nepal. The civil society interface between China and South Asia remains limited (Blaikie and Muldavin 2004).

Given the ecological complexity and political sensitivities of regional environmental governance, it is important to envision multiple pathways and approaches for regional knowledge-sharing and policy engagement platforms. Such platforms could be helpful not only in shaping common policy agendas, but also in fostering regional exchange for the development and implementation of common methodologies at the landscape level. Systematic documentation and sharing of local-level good practices - such as those related to watershed management, poverty reduction, and community-based environmental management and climate change adaptation-would greatly enrich the regional knowledge-sharing platform and help in crafting a regional-level collaborative mechanism.

\subsubsection{Emerging Mechanisms for Managing Conflicts and Equitably Distributing Benefits}

The issue of upstream and downstream relationships for the allocation of resources, especially of water and responsibility for managing the watershed, is challenging, and the future 
possibility of collaboration, especially along the Himalayan rivers, will depend on how the distributional issue is resolved in the region. Power imbalances among the participating countries and the domination of bigger economies in extracting natural resources have historically been a barrier to identifying just and fair institutional mechanisms. Smaller economies, which are primarily dependent on subsistence relationships with natural resources, are in conflict with the dominant political and economic interests in the HKH. Disputes and contentions over transboundary water management and allocations persist (Uprety and Salman 2011)

Studies at multiple levels have shown that there is an urgent need for a shared framework and understanding on natural resources governance at the regional scale, supported by appropriate institutions (Blaikie and Muldavin 2004; Tiwari and Joshi 2015). These institutions could include (1) special provisions for mountain regions - especially in countries such as China, India, and Pakistan, where mountains are not the focus of policy processes, and (2) mechanisms and processes for collaboration through which the interests and priorities of the smaller HKH countries, which are caught between larger geopolitical interests, could be protected to facilitate the fair distribution of the costs and benefits of regional transboundary resource management.

Institutional innovations, an eco-regional development framework, and ecological connectivity across national borders are paramount for ensuring the sustainable future of the HKH. Indeed, a range of institutions for transboundary collaboration has emerged in recent years (Tiwari and Joshi 2015). Included among existing institutions are the age-old practices of transboundary community cooperation in natural resource management, such as communities involved in cross-border herding along the mountain frontiers of China, India, and Nepal (Sharma and Chettri 2005). However, there is still no robust regional framework for collaborative resource management among the HKH countries (Tiwari and Joshi 2015), and current practices of regional cooperation are not driven by the goal of enhancing ecological integrity or long-term social wellbeing (Bawa et al. 2010). With two of the major economies - China and India-located on the two sides of the Himalayan range, there is an immense possibility for regional cooperation to help "mitigate climate change, environmental damage, and biodiversity loss both regionally and globally" (ibid.).

The existing regional governance and collaboration efforts are based mainly on geopolitical and political economic interests rather than conservation and social interests. In developing the Himalaya as an eco-region, beyond the political boundaries, the role and involvement of Chinese institutions and communities will be decisive. Half of the $\mathrm{HKH}$ eco-region lies within China, but the role of China in the region remains limited to natural resource trade and a few donor-designed conservation projects. Common resource management in the current situation of geopolitical tension and political and economic competition remains uncertain, and there are no substantial efforts underway to generate political will at the national and intergovernmental levels. The future for regional governance of natural resource management in the region will depend to a large extent on whether innovative institutional arrangements emerge to facilitate intergovernmental dialogue, common policy initiatives, and collaborative transborder community practices beyond the state of conflict, as demonstrated in various forms of transboundary water interactions (Sahni 2006). The pathway to prosperity in the region, as elaborated in Chap. 4, Scenarios, is through large-scale investments and regional cooperation across multiple scales.

\subsection{The Need for Strengthening Cross-Scalar Interfaces and Adaptive Governance}

With greater recognition of the HKH's complex geographical and political environment, diverse social systems, and upstream-downstream interconnectedness, attention should be paid to strengthening linkages among institutions across scales, building an effective interface among the various knowledge-based systems (Weiss et al. 2012), and creating new bridging institutions for transformative governance (Huitema et al. 2009). Given the wider concerns about environmental resilience and social equity outcomes, there is a growing consensus in the scientific community, which manifests in the environmental governance literature, on two processes identified as crucial. First is the need to embrace an adaptive approach to environmental governance (Cooper and Wheeler 2015), and second is the need to ensure an inclusive participatory process in decision making and benefit sharing (Blaikie and Sadeque 2000; Saravanan 2009; Ojha and Hall 2013). These requirements indicate the desirability of a multi-level governance approach, as this approach underscores four underlying principles of adaptive governance: management on a bioregional scale, polycentric governance, public participation, and experimentation (Huitema et al. 2009). To support these processes, a complex combination is required of "openness of practices, active involvement of key actors, strong but inclusive leadership, and a knowledge-based hybrid multi-level network combining horizontal and vertical network governance" (Naustdalslid 2015: 913).

Scholarly research on multi-scalar governance in the context of the developing world found it "too underdeveloped to make any serious evaluation" (Stephenson 2013: 830). Research in global governance supports the idea that centralized governments must give way to co-management that 
opens up different levels of control and governance (Pahl-Wostl et al. 2008) and helps tackle issues related to uncertainties and the persistent lack of communication among environmental stakeholders (Weiss et al. 2012). Furthermore, the interactions between policy-making arrangements (Piattoni 2015) and institutions at multiple levels and scales are continuously shaping both development and governance outcomes (Cash et al. 2006). This means that achieving more politically and ecologically sustainable solutions to problems requires addressing scale issues and creating dynamic linkages across levels (Cash et al. 2006; Piattoni 2015). Multi-level governance involves vital linkages connecting mutually dependent governance levels with cross-scalar processes of policy making, planning, and implementation activities (Stephenson 2013), and is also seen as a form of polycentric governance involving co-management (Andersson and Ostrom 2008). Such framing of governance helps to understand how, where, and for whom governance decisions affecting sustainable development are made (Wilbanks 2007) and how they can be improved.

Below, we examine the key aspects of current multilevel and cross-scalar governance, both worldwide and in the $\mathrm{HKH}$, and further explore why multilevel governance is crucial for the region.

\subsubsection{Emerging Mechanisms for Managing Conflicts and Equitably Distributing Benefits}

While in some environmental sectors, institutional governance is lacking, others are marred by excessive or overly complex institutional arrangements. Our analysis revealed a disconnect in all the HKH countries between policies and institutions for forest, rangeland, and water (see Sects. 16.3 and 16.4). The issue of institutional fragmentation is not new; the persistent failure to ensure coordination and build linkages and synergies among the wide range of environmental institutions is widespread in the HKH. The challenge is further compounded by the fact that, historically, the environmental sector in the region has been organized under separate knowledge disciplines, and institutions have mostly evolved across resource sectors as a result of organization according to discipline and sectoral divisions. Accordingly, a number of resource specific institutions have emerged in various sub-sectors of the environment, including forest, rangeland, and water, across the community, public, and private domains.

There are reported cases of institutions in each sector operating mostly in silos, often in contradiction to one another, as the mechanisms and strategies for integration and coordination remain weak. There is also a lack of effective institutions for resource management. This is exemplified in the HKH by upstream-downstream river basin management (Shrestha et al. 2013). The lack of such institutions is now felt, as there is a vacuum in catering to the various management needs which arise in different parts of these basins. Meeting these needs requires local and national governments to co-manage cross-border water resources (Pigram 2000; Moellenkamp 2007), but the formal institutional settings, policies, and research in the HKH are far too limited for this. Further, cross-border river basins place national and regional governance in juxtaposition with local-level governance, necessitating more integration (Molle 2009; Pahl-Wostl et al. 2008)

\subsubsection{The Imbalance Between Vertical and Horizontal Distribution Under Multilevel Governance}

There is an asymmetrical distribution of power and authority across different levels (as well as domains) of governance, as the central governments in all eight HKH countries play the primary role of formulating policies and enacting laws without necessarily engaging the stakeholders in lower levels of governance. The currently dominant normative paradigm of governance emphasizes the state as the legitimate site of authority; unless this authority is delegated or enacted through polycentric institutions, there is a tendency to overlook the importance of decision making at lower scales of governance. At present, however, both local and national jurisdictions are difficult to exercise, as local- and national-level environmental challenges become increasingly intertwined (Rosenau et al. 2004).

While the strengthened role of central and subnational-level authorities has made it possible for governments to adapt policies and practices to suit their own context and priorities (Jörgensen et al. 2015), central-level policymaking and implementation have largely occurred in isolation from, or in contradiction to, both supranational and local levels. State-centred governments are known to prioritize large-scale infrastructure, have vested political and financial interests, ignore local processes and hydrological interconnectedness, and neglect environmental degradation (Molle and Mamanpoush 2012). For example, the governance of water resources in Bangladesh is biased toward structural solutions of flood control and irrigation using a centralized approach that ignores the many other uses of water, such as drinking and sanitation, fisheries, navigation, and ecology (Chowdhury and Rasul 2011: 44).

Research has shown that addressing the complex problems of the environment requires a mix of institutions and designs that facilitate experimentation, learning, and change (Dietz et al. 2003). This entails a governance structure based on collaboration, which occurs when different government 
bodies work together with non-governmental stakeholders and interest groups to manage issues that cross jurisdictional boundaries and fall into different natural resource management policy sectors (Huitema et al. 2009). Multilevel bioregional approaches to water management have been institutionalized in the EU's Water Framework Directive (WFD). Research suggests that the concept of multilevel governance could be useful in cultural contexts outside the $\mathrm{EU}$, if it takes indigenous governance concepts and ideas of scale into account and maps power relations in the making and implementation of policies (Hensengerth 2015).

The HKH countries have yet to capitalize on the opportunities created by the proliferation of stakeholders in environmental governance, and in the worst cases, the centralized and state-centric systems continue to function alongside the novel arrangements. The perils of a strong centralized system are exemplified in the institutional settings in the State of Uttarakhand in India. Studies show that linkages among public institutions like the jal nigam, jal sansthan, Water Directorate, and Urban Development Directorate are not only poor but also conflicting, as their functions overlap with other governing bodies like the community-level water users' groups and municipal corporations, which also have some authority for water management, especially on the supply side.

Further experience suggests that the desired environmental and social outcomes are not necessarily achieved when national-level institutions have a dominant influence. For example, Bangladesh's overarching policy on natural resource management has traditionally been focused on earning revenue for the government. In pursuing this policy, natural resource management typically depended on public bureaucracy, which essentially followed a policing, exclusionary, and non-participatory approach to operations (Khan 1998; Chowdhury and Khan 2017). This trend has led to a number of outcomes: (1) resultant alienation of the local communities from the management and use of natural resources; (2) creation and patronization of an elitist aristocracy who enjoyed de facto privatized control and authority over funds and acted as intermediaries between the state and local communities; (3) systematic undermining of local institutions, community initiatives, customary rights, and wisdom in natural resource management; and 4) overshadowing of broader sustainability and environmental considerations in the management of funds (Khan and Harriss-White 2012: 103). Often, the access to water resources and the costs and benefits of water resource projects are distributed unequally; while the rich gain more access to water resources, the poor bear the cost (Chowdhury and Rasul 2011: 44).

Evidence on the outcomes of decentralization and devolution in the HKH also underscores both the potential and, more importantly, the limits of local governance in the
Himalaya. Research reveals that co-governance, in place of local autonomy, can still lead to inferior outcomes when the central actors wish to retain supervision of the decentralized institutions, which contradicts the concept of organic linkages between indigenous management and knowledge systems and causes tension in the politics of decentralization of natural resources. One analysis suggests that because of this tension, the forests in Himachal are in a worse condition under the co-governance management regime than under the indigenous system (Agrawal and Chhatre 2006). Therefore, it is important to incentivize policies that encourage the development of proper polycentric systems for natural resource governance to maintain local benefits while increasing the capacity to deal with socioecological challenges (Bixler 2014). Lessons from co-management arrangements in the forest and wetlands in Bangladesh indicate that links with local government and formal recognition of CBOs are important in establishing their legitimacy to represent community interests and in overcoming conflicts (Khan and Harriss-White 2012).

The multilevel governance framework provided in the case of Chinese hydropower suggests that even strongly nation-state-centric governance regimes need not automatically be top-down, but can be highly fragmented and subject to complex and multi-scalar decision-making processes. In China, informal networks between the energy bureaucracy and hydropower developers determine the hydropower decision-making process. These informal networks sit starkly at odds with China's state-centric governance system. By putting authoritarian and indigenous governance concepts together, vibrant and reflexive systems of governance with adaptive skills are finding their way into the hitherto state-dominated Chinese hydropower governance, with a dominance of informal networks in the decision-making process compared to the formal bureaucratic approach (Hensengerth 2015).

\subsubsection{The Emerging Role of Knowledge Interfaces in the Shift Towards Adaptive Governance}

The building of co-management and cross-border management structures depends heavily on knowledge co-production, mediation, translation, and negotiation (Cash et al. 2006).

The first point is that improving communication links between knowledge producers and policy makers in environmental management is important for evidence-based decision making (Weiss et al. 2012). The use of feedback and reflections to improve and prepare a governance system to tackle unprecedented risks and shocks is a key part of adaptive governance. However, policy-monitoring 
mechanisms vary across the HKH countries, as does their use of research and feedback from practice in policy making and governance decision making. In water resource management, China has adopted the practice of first piloting, learning from the experience, and then applying the revised policies and laws to the entire country. In contrast, in Nepal's forest sector, policy-making processes are not informed by scientific research (Ojha et al. 2016b); despite the growing body of research, policy review and revisions are ad hoc and often driven by external donors or international agencies. In Bhutan, proposed policies are passed through a policy-screening tool developed on the principles of gross national happiness. Midterm and end of Five-Year Plan reviews provide an opportunity to review policies and implementation. The guidelines for development of Five-Year plans to some extent incorporate revisions based on these reviews.

The second point is that knowledge is produced and understood at different scales, and bringing clarity to a mismatch of scales is integral to knowledge use. Scalar issues pertaining to knowledge in natural resource management and environmental assessments deeply influence governance and policy making. Research suggests that the integration of local and scientific knowledge must be open to questioning how different knowledge systems may be fundamentally embedded in different scales, influencing problem definition and solutions. Both local traditional knowledge and scientific knowledge are contextual and applied, diverse and inherently multi-scalar. Therefore, "scale politics and mismatch between scales of knowledge exist within local communities", and scientific knowledge will inevitably interfere politically with local knowledge. Ahlborg and Nightingale (2012: 16) argue that "it is not simply the case that one needs to confer with local actors or elites or those considered local experts; rather, one needs to attend to how scales of knowledge produce a politics of knowing that can have real implications for on-the-ground management".

Insufficient data and lack of monitoring capability are major obstacles to proactively seeking, synthesizing, and using both experiential and scientific knowledge to support decision making in conditions of uncertainty. The ability to do this is a key part of adaptive governance. At times, decisions are made when contradictory claims to knowledge exist, resulting in unclear and confusing policy directions. For example, in Pakistan, many researchers have argued that the actual forest area of the country is much lower than that officially claimed, as a result of definitional and jurisdictional issues (Shahbaz 2009). In Nepal, despite a plethora of studies conducted into forestry and agriculture in the hills, there is still a lack of information about what is happening on the ground at different locations, or analysis of the impact of different community-based resource management regimes. Studies are also divided across three key sectorsland management, forestry, and agriculture - and there is limited knowledge on cross-sectoral interactions.

Critical insights have, however, emerged as to how research can be linked to practice and policy processes. For example, in Nepal's forestry system (Banjade 2013; McDougall et al. 2013; Ojha et al. 2010), studies show that alliance-led resistance and research-informed deliberation can overcome threats of recentralization (Sunam et al. 2013). However, even with relevant and emerging research, the quality and form of presentation is often not strong enough to attract the attention of, or to be compatible with, policy actors and community leaders.

There are a few systematic, longitudinal studies that have used robust methodologies and have intimately engaged with the contexts, but these studies are often shaped by the interests of the sponsors. Studies are framed either as global knowledge questions or donor project objectives, and there have been few engaged research attempts to critically expose or contribute to local decision systems that impact smallholder agriculture and forestry. This is because the agenda of sustainability in development is promoted by international aid agencies. There is a long history of scientific claims that development interventions have failed to achieve their intended goals, a matter that has become a key base to advance theorizing on the problems of and potential solutions for the Himalaya (Thompson and Warburton 1985; Ives et al. 1987; Ives and Messerli 1989; Blaikie et al. 2002; Ives 2004). The Himalayan myth (that the region was facing an environmental disaster due to rapid population growth, causing extensive deforestation) was based on a discredited western scientific construct (Ives et al. 1987; Bruijnzeel and Bremmer 1989; Ives 1989, 2004; Ives and Messerli 1989; Guthman 1997; Forsyth 1998), but it has created confusion and led to assumptions and misinterpretations about the Himalaya that have affected development planning and implementation and led to misguided research efforts (Ives et al. 1987; Ives 2012). The overgeneralization of complex problems and their solutions in the $\mathrm{HKH}$ has led to a failure in development-oriented research (Ives 2012).

China's adoption of the practice of piloting laws and revising them on the basis of implementation experience is an interesting move toward adaptive governance. For example, the Environmental Protection Law of 1979 was enacted on a trial basis and, because it proved more solution-oriented than based on proactive prevention, was amended and reenacted in December 1989. Likewise, under the perceived situation of the tragedy of the commons, reforms in cropland regions saw a transformation from communal management of rangelands to autonomous individual household responsibility over farm management (Banks et al. 2003). In Bhutan, natural resources, especially Sokshing (homestead leaf litter forests), Tsamdrog 
(rangelands), and water have been nationalized through enactment and revision of the Land Act (RGOB 2007), the Forest and Nature Conservation Act (RGOB 1995), and the Water Act (RGOB 2011) for the sole purpose of conservation and sustainable utilization. In recent times, degradation of the natural environment resulting from mining activities, with no tangible economic benefits to the government and communities, has led to the emergence of policies to limit the private sector and initiate state engagement in harnessing the economic potential of natural resources, demonstrating that adaptive policy making can work in a complex political environment, as exemplified earlier by the evolution of community forestry policy in Nepal. On the other hand, there have also been significant developments in the area of water resource management. In its effort to implement the Water Act of 2014, Bhutan adopted the National Integrated Water Resource Management Plan (NIWRMP), which calls for water security as a national goal to be achieved through employment of the Bhutan Water Security Index (BWSI) and associated interagency coordination framework for planning, implementation, monitoring, and reporting progress.

Cote and Nightingale (2012) argue that the conceptualization of social change in environmental research is itself problematic, as it emphasizes a focus on the structures and functionality of an institutional system devoid of political, historical, and cultural meaning. Greater efforts at situating definitions and questioning formulations about resilience within political and cultural heterogeneities can help address both this issue and the underlying normative concerns. We believe that the question of adaptability and resilience of the environmental governance system depends to a large extent on the role of knowledge at the intersection between social and environmental dynamics, and the ways in which the politics of knowledge helps to address normative questions in the context of power asymmetry and competing value systems - all of which are not external to, but rather integral to the development and functioning of an environmental management system. Fundamentally speaking, it is important to consider how various systems of knowledge are mobilized and an effective interface is created. Researchers should not overlook the importance of engagement with policy actors at different stages of research.

\subsubsection{The Emerging Emphasis on Multilevel Learning for Inclusive Policies and Transformational Governance}

Evidence suggests that the efforts to ensure inclusion in governance are not fully informed by the unfolding social and political dynamics. We argue that inclusive policy processes should not only be restricted to cross-scalar policy and institutions, but also that they be prioritized within scales and at all levels by increasing the level of participation and democratic representation of stakeholders, individuals, and marginal social groups. Further, institutions need to be flexible and to encourage reflection, learning, experimentation, and innovative responses to specific local capabilities and needs. Institutional arrangements which facilitate multilevel learning are critical for exploring uncertainties and finding solutions for climate change adaptation (Huntjens et al. 2012), which is now a global preoccupation.

Sustainable development also requires transformational adaptation to changes in underlying cultural and political systems, not just adaptation of specific management practices (Pelling 2011). This approach requires environmental policy and institutions to embrace social learning while undertaking the governance and management of natural resources (Olsson et al. 2006; Leach et al. 2007; Plummer et al. 2013). Indeed, governance itself is a process of learning in relation not only to management operations but also to fundamental cultural values and political standpoints (Dressler et al. 2010).

While it is clear that inclusive policy processes help to ensure a more just governance process, it is not clear which governance structures are best for doing this. Research suggests that monocentric perspectives are better at ensuring public participation, as it is easier to provide feedback to the public through a central structure. Similarly, management as experimentation may work better in a monocentric system than in a polycentric one. However, in the case of river basins, unitary authorities at the sub-basin or watershed level may be better at connecting the public with the central authorities (Huitema et al. 2009). Local-level institutions can provide space for the empowerment of historically marginalized groups, but this representation can sometimes be tokenistic at best (Cooke and Kothari 2001; Nightingale 2002; Sikor and Lund 2009). Social inclusion can be freed from rhetoric if the monitoring mechanisms prioritize communication and the use of feedback and reflections to improve governance.

Finally, the shift in gender roles in both mountainous and peri-urban contexts has potentially profound implications for inclusion in governance. As an example, urbanization or rural-urban migration can lead to a transformation of gender relations around water in particular, as well as around natural resources more broadly. It is also argued that with the acquisition of village grazing lands to support urban expansion, gender relations around natural resources can be transformed (Vij and Narain 2016). In India, studies have shown that men performed the task of water collection in upper-caste households, but with occupational diversification, this task is increasingly being performed by women (Ranjan and Narain 2012). In other areas, efforts have been made to reduce women's drudgery in water collection in the mountains by bringing water sources closer to homes, but 
these efforts proved limited in their impact on improving women's quality of life. Along with climate change, both urbanization and rural-urban migration create new demands on women's time in mountain contexts, while the expansion of a water supply may itself create new water collection tasks (Narain 2014). Thus, focusing on changing gender relations around water may yield a better understanding of the impacts of drinking water supply interventions on women's quality of life than estimating impact simply in terms of conventional indicators of women's water burdens.

\subsection{Opportunities for Improving Environmental Governance in the HKH}

This chapter has provided an assessment of environmental governance in the Hindu-Kush Himalaya, encompassing processes at local, national, and regional scales. It shows that the governance of environmental resources in the region involves a complex ensemble of state policy frameworks, policy making and implementing organizations, knowledge communities, traditional institutions, and the private sector. The field of environmental governance entails pluralistic and highly dispersed authorities at local, subnational, national, regional, and global levels. The distribution of governing power across various levels of governance is unbalanced and often incompatible with the sustainable management of natural resources. Environmental institutions have yet to fully recognize the complex Himalayan geography, which is characterized by the lack of appropriate, context-specific institutions to link upstream and downstream communities in river basins.

National environmental policies and institutions in the region are complex and still evolving. Governance reforms include the adoption of new environmental concerns such as climate change, disaster risks, and biodiversity; decentralization and devolution; and new shifts to adopt market mechanisms in resource governance. While policy visions and frameworks for improved environmental governance have emerged in response to the change in contexts, there is a lack of effective implementation. This is because developing new policy visions is not concurrently linked to a process of institutional reform. The link between policy and practice is poor, and many of the lessons learned from the field - as well as evidence from research - goes unused in national policy processes.

A variety of decentralization initiatives have emerged with significantly positive outcomes in different localities, yet these are not adequately supported or institutionalized in the national and subnational systems of governance. Regional cooperation on environmental issues remains limited, and there is an urgent need for the HKH countries to engage more meaningfully in devising frameworks for fair cooperation, as countries have intimate upstream and downstream linkages, complementary expertise and experiences, and differing levels of national capability and negotiating power. The future of regional governance of natural resource management depends to a large extent on how innovative institutional arrangements emerge in the region to facilitate intergovernmental dialogue, common policy initiatives, and collaborative trans-border community practices, beyond the dichotomy of cooperation and conflict which has existed in varied forms of transboundary management of natural resources.

Given the rich experiences and policy experiments in diverse sub-regions and localities in the HKH, there is an important need to strengthen the cross-scalar knowledge interface and inclusive governance processes - both within and between the nation-states - to ensure fair and adaptive governance in the face of the growing risks related to climate change and disaster in the Himalaya.

The findings show that there are at least four opportunities for improving environmental governance in the region: (1) strengthening the interface between science, policy, and practice; (2) strengthening the institutional capacity to implement new policies; (3) scaling up community-based environmental management systems by creating more enabling regulatory frameworks and appropriate local institutional arrangements; and (4) strengthening transboundary cooperation among the HKH countries.

\section{References}

Acharya, K. P. (2002). Twenty-four years of community forestry in Nepal. International Forestry Review, 4(2), 149-156.

Acharya, K. P. (2004). Does community forest management support biodiversity conservation: Evidences from two community forests from the middle hills of Nepal. Journal of Forest and Livelihood, 4(1).

Acharya, K. P., Adhikari, J., \& Khanal, D. R. (2008). Forest tenure regimes and their impact on livelihoods in Nepal. Journal of Forest and Livelihood, 71, 6-18.

Agarwal, A., \& Narain, S. (2002). Community and household water management: The key to environmental regeneration and poverty alleviation. New Delhi: Concept Publishing Company.

Agrawal, A. (2001). The regulatory community: Decentralization and the environment in the van panchayats (forest councils) of Kumaon, India. Mountain Research and Development, 21(3), 208-211.

Agrawal, A., \& Yadama, G. (1997). How do local institutions mediate market and population pressures on resources? Forest Panchayats in Kumaon, India. Development and Change, 28, 435-465.

Agrawal, A., \& Gibson, C. C. (1999). Enchantment and disenchantment: The role of community in natural resource conservation. World Development, 27(4), 629-649.

Agrawal, A., \& Chhatre, A. (2006). Explaining success on the commons: Community forest governance in the Indian Himalaya. World Development, 34(1), 149-166.

Agrawal, A., \& Lemos, M. C. (2007). A greener revolution in the making? Environmental governance in the 21st century. Environment: Science and Policy for Sustainable Development, 49(5), 3645. http://dx.doi.org/10.3200/ENVT.49.5.36-45. 
Agrawal, A., \& Verma, R. (2017). Natural resource governance at multiple scales in the Hindu Kush Himalaya. International Centre for Integrated Mountain Development (ICIMOD) Working Paper $2017 / 4$

Ahlborg, H., \& Nightingale, A. J. (2012). Mismatch between scales of knowledge in Nepalese forestry: Epistemology, power and policy implications. Ecology and Society, 17(4), 16. https://doi.org/10. 5751/ES-05171-170416.

Ali, A., \& Shaoliang, Yi. (2013). Highland rangelands of Afghanistan: Significance, management, issues and strategies. In W. Ning, G. S. Rawat, S. Joshi, M. Ismail, \& E. Sharma (Eds.), High-altitude rangelands and their interfaces in the Hindu Kush Himalayas (pp. 15-24). Kathmandu: ICIMOD.

Ali, J., \& Nyborg, I. L. P. (2010). Corruption or an alternative system? Re-assessing corruption and the role of the forest services in the northern areas. Pakistan. International Forestry Review, 12(3), 209-220.

Andersson, K. P., \& Ostrom, E. (2008). Analyzing decentralised resource regimes from a polycentric perspective. Policy Sciences, 41(1), 71-93.

Bacho, F. Z. L. (2005). Decentralization in a pluralist state: Ethnic identity, resource conflicts and development in the East Gonja district of Ghana. Ghana Journal of Development Studies, 2(1).

Baginski, O. S., \& Blaikie, P. (Eds.). (2007). Forests, people and power: The political ecology of reform in South Asia. London: Earthscan.

Banjade, M. R. (2013). Learning to improve livelihoods: Applying adaptive collaborative approach to forest governance in Nepal. In $\mathrm{H}$. Ojha, A. Hall, \& V. R. Sulaiman (Eds.), Adaptive collaborative approaches in natural resource governance: Rethinking participation, learning and innovation. London: Routledge.

Banks, T., Richard, C., Ping, L., \& Zhaoli, Y. (2003). Community-based grassland management in western China. Mountain Research and Development, 23(2), 132-140.

Bardhan, P. (2002). Decentralisation of governance and development. The Journal of Economic Perspectives, 16(4), 185-205.

Barnes, C., \& Laerhoven, F. V. (2014). Making it last? Analysing the role of NGO interventions in the development of institutions for durable collective action in Indian community forestry. Environmental Science \& Policy, 53, 192-205.

Bawa, K. S., Koh, L. P., Lee, T. M., Liu, J., Ramakrishnan, P., Douglas, W. Y., et al. (2010). China, India, and the environment. Science, 327(5972), 1457-1459.

Bhattacharya, P., Pradhan, L., \& Yadav, G. (2010). Joint forest management in India: Experiences of two decades. Resources, Conservation and Recycling, 54(8), 469-480.

Bhattarai, B., Dhungana, S. P., \& Ojha, H. (2007). Poor-focused common forest management: Lessons from leasehold forestry in Nepal. Forest and Livelihood, 6(2), 20-29.

Bhattarai, S., kumar Jha, P., \& Chapagain, N. (2009). Towards pro-poor institutions: Exclusive rights to the poor groups in community forest management. Discussion paper. Kathmandu: ForestAction.

Biswas, A. K. (2011). Cooperation or conflict in transboundary water management: Case study of South Asia. Hydrological Science Journal, 56(4), 662-670.

Bixler, R. P. (2014). From community forest management to polycentric governance: Assessing evidence from the bottom up. Society and Natural Resources, 27(2), 155-169. http://doi.org/10.1080/ 08941920.2013 .840021$.

Blaikie, P. (2006). Is small really beautiful? Community-based natural resource management in Malawi and Botswana. World Development, 34(11), 1942-1957.

Blaikie, P. M., \& Sadeque, S. Z. (2000). Policy in high places: Environment and development in the Himalayan region. ICIMOD.
Blaikie, P., Cameron, J., \& Seddon, D. (2002). Understanding 20 years of change in West-Central Nepal: Continuity and change in lives and ideas. World Development, 30(7), 1255-1270.

Blaikie, P., \& Muldavin, J. S. S. (2004). Upstream, downstream, China, India: The politics of environment in the Himalayan region. Annals of the Association of American Geographers, 94(3), 520-548.

Brichieri-Colombi, S., \& Bradnock, R. W. (2003). Geopolitics, water and development in South Asia: Cooperative development in the Ganges-Brahmaputra delta. The Geographical Journal, 169(1), 4364.

Bruijnzeel, L. A., \& Bremmer, C. N. (1989). Highland-lowland interactions in the Ganges Brahmaputra river basin: a review of published literature. ICIMOD Occasional Paper No. 11. Kathmandu: ICIMOD.

Butler, C. J. (2016). Knowledge, nature, and nationalism: The Upper Karnali dam in Nepal. Doctoral dissertation, University of California, Santa Cruz.

Capistrano, D. (2012). Decentralization and forest governance in Asia and the Pacific: Trends, lessons and continuing challenges. In C. J. P. Colfer, G. R. Dahal, \& D. Capistrano (Eds.), Lessons from forest decentralization: Money, justice and the quest for good governance in Asia-Pacific (pp. 211-232). London: Earthscan.

Cash, D. W., Adger, W. N., Berkes, F., Garden, P., Lebel, L., Olsson, P., et al. (2006). Scale and cross-scale dynamics: Governance and information in a multilevel world. Ecology and Society, 11(2), 8.

Chapagain, N., \& Banjade, M. R. (2009). Community forestry and local development: Experiences from the Koshi hills of Nepal. Journal of Forest and Livelihood, 8(2), 78-92.

Chettri, N., Shakya, B., Thapa, R., \&Sharma, E. (2008). Status of a protected area system in the Hindu Kush-Himalayas: An analysis of PA coverage. International Journal of Biodiversity Science and Management, 4,164-178.

Chhetri, B. B., Schmidt, K., \& Gilmour, D. (2009). Community forestry in Bhutan-exploring opportunities and facing challenges. In Community forestry international workshop, Pokhara, Nepal.

Chowdhury, J. K. (2001). Does forestry pay in Bangladesh? Lessons from $A D B$ 's forest sector projects. Paper presented in the Forestry Sector Workshop, organized by the Forest Department and the ADB, December 3-5, 2001, Dhaka.

Chowdhury, A. A. M., \& Khan, N. A. (2017). Participatory forestry in Bangladesh: Practices among selected ethnic communities in Chittagong Hill Tracts. Dhaka: OSDER Publications.

Chowdhury, A. K. M. J. U., \& Rasul, G. (2011). Equity and social justice in water resource governance: The case of Bangladesh. South Asia Water Studies, 2(2), 44-58.

Cooke, B., \& Kothari, U. (2001). Participation: The new tyranny?. New York: Zed Books.

Cote, M., \& Nightingale, A. J. (2012). Resilience thinking meets social theory: Situating social change in socio-ecological systems (SES) research. Progress in Human Geography, 36(4), 475-489.

Cooper, S. J., \& Wheeler, T. (2015). Adaptive governance: Livelihood innovation for climate resilience in Uganda. Geoforum, 65, 96-107.

Crook, R. C. (2003). Decentralisation and poverty reduction in Africa: The politics of local-central relations. Public Administration and Development, 23(1), 77-88.

Crow, B., \& Singh, N. (2000). Impediments and innovation in international rivers: The waters of South Asia. World Development, 28(11), 1907-1925.

Cumming, G. S. (2011). The Resilience of Big River-basins. Water International, 36(1), 63-95.

Dahal, G. R., \& Chapagain, A. (2005). Community forestry in Nepal: Decentralized forest governance. In C. J. P. Colfer, G. R. Dahal, \& D. Capistrano (Eds.), Lessons from forest decentralization: Money, justice, and the quest for good governance in Asia-Pacific (pp. 6782). London: Earthscan. 
Denholm, J. (1991). Agroforestry in mountain areas of the Hindu Kush-Himalayan Region. ICIMOD Occasional paper (17).

Dietz, T., Ostrom, E., \& Stern, P. (2003). The struggle to govern the commons. Science, 302(5652), 1907-1912.

Dong, S., Lassoie, J., Shrestha, K. K., Yan, Z., Sharma, E., \& Pariya, D. (2009). Institutional development for sustainable rangeland resource and ecosystem management in mountainous areas of Northern Nepal. Journal of Environmental Management, 90(2), 994-1003. http://doi.org/10.1016/j.jenvman.2008.03.005.

Dorji, C. (2007). Mountain development in South Asia. Sustainable Mountain Development, 53.

Dorji, L., Webb, E. L., \& Shivakoti, G. P. (2006). Forest property rights under nationalized forest management in Bhutan. Environmental Conservation, 33(2), 141-147.

Dressler, W., Bram, B., Michael, S., Brockington, D., Hayes, T., Kull, C., et al. (2010). From hope to crisis and back again? A critical history of the global CBNRM narrative. Environmental Conservation, 37(1), 1-11.

Farooquee, N. A., Majila, B., \& Kala, C. (2004). Indigenous knowledge systems and sustainable management of natural resources in a high altitude society in Kumaun Himalaya, India. Journal of Human Ecology, 16(1), 33-42.

Fisher, R. J. (1989). Indigenous systems of common property forest management in Nepal. Issue 18 of Working paper. Hawaii: East-West Environment and Policy Institute.

Fleischman, F. D. (2014). Why do foresters plant trees? Testing theories of bureaucratic decision-making in Central India. World Development, 62, 62-74.

Forsyth, T. (1998). Mountain myths revisited: Integrating natural and social environmental science. Mountain Research and Development, 18(2), 107-116.

Friend, R., Jarvie, J., Reed, S. O., Ratri, S., Pakamas, T., \& Canh, T. V. (2013). Mainstreaming urban climate resilience into policy and planning: Reflections from Asia. Urban Climate, 7, 6-19.

Fung, A., \& Wright, E. O. (2001). Deepening democracy: Innovations in empowered participatory governance. Politics and Society, 29(1), $5-41$.

Gautam, M. S., \& Pokhrel, B. (2011). Foreign aid and public policy process in Nepal: A case of forestry and local governance. Discussion Paper 3. Kathmandu: Southasia Institute of Advanced Studies.

Gautam, A. P., Webb, E. L., \& Eiumnoh, A. (2002). GIS assessment of land use/land cover changes associated with community forestry implementation in the Middle Hills of Nepal. Mountain Research and Development, 22(1), 63-69.

Gautam, A. P., Shivakoti, G. P., \& Webb, E. L. (2004). A review of forest policies, institutions, and changes in the resource condition in Nepal. International Forestry Review, 6(2), 136-148.

Ghate, R., \& Chaturvedi, R. (2016). Unpacking the governance conundrum for better natural resource management. ICIMOD Working Paper (2016/2).

Ghosh, D. K. (2008). Governance at local level: the case of panchayats in West Bengal. The Indian Journal of Political Science, 71-88.

Gilmour, D. A. (1990). Resource availability and indigenous forest management systems in Nepal. Society \& Natural Resources, 3(2), $145-158$.

Gilmour, D. A., \& Fisher, R. J. (1991). Villagers, forests, and foresters: The philosophy, process, and practice of community forestry in Nepal.

Goldstein, A., Pinaud, N., \& Reisen, H. (2006). The rise of China and India: What's in it for Africa?. OECD Development Centre Policy Insights, No. 19. Paris: OECD Publishing. http://dx.doi.org/10. $1787 / 246616177271$.

GOM. (1992). Forest Law 1992. Forest Department, Ministry of Natural Resources and Environmental Conservation. Government of Myanmar.
GOM. (1995a). Forest Policy 1995. Forest Department, Ministry of Natural Resources and Environmental Conservation. Government of Myanmar.

GOM. (1995b). Community forestry instructions. Forest Department, Ministry of Natural Resources and Environmental Conservation, Government of Myanmar.

GOM. (2008). Constitution of Myanmar 2008. Government of Myanmar [pdf] Available at: http://asean-law.senate.go.th/files/ Myanmar2008.pdf.

GON. (1975). Agreement between His Majesty's Government of Nepal and the Government of India on the Gandak Irrigation and Power Project. Kathmandu: Ministry of Water and Power, Government of Nepal.

Gongbuzeren, Yanbo Li, \& Li, Wenjun. (2015). China's rangeland management policy debates: What have we learned. Rangeland Ecology \& Management, 68(4), 305-314.

Groninger, J. W. (2012). Reforestation strategies amid social instability: Lessons from Afghanistan. Environmental Management, 49(4), 833-845.

Grumbine, R. E., \& Pandit, M. K. (2013). Threats from India's Himalaya dams. Science, 339(6115), 36-37.

Guangwei, C. (2002). Biodiversity in the eastern Himalayas: Conservation through dialogue. Summary reports of workshops on biodiversity conservation in the Hindu Kush-Himalayan ecoregion. In Biodiversity in the eastern Himalayas: Conservation through dialogue. Summary reports of workshops on biodiversity conservation in the Hindu Kush-Himalayan ecoregion. ICIMOD.

Guthman, J. (1997). Representing crisis: The theory of Himalayan environmental degradation and the project of development in Post-Rana Nepal. Development and Change, 28(1), 45-69.

Guttman, H. (2003). The Mekong river-basin: Practical experiences in transboundary water management in free flow: Reaching water security through cooperation. In J. Griffiths \& R. Lambert (Eds.), Free flow: Reaching water security through cooperation. UNESCO.

Halder, S., \& Thompson, P. (2006). Community based co-management: A solution to wetland degradation in Bangladesh, MACH Technical Paper 1. Management of Aquatic Ecosystem through Community Husbandry Project, Dhaka: Winrock International.

Hensengerth, O. (2015). Multi-level governance of hydropower in China? The problem of transplanting a Western concept into the Chinese governance context. In Multi-level governance: The missing linkages (pp. 295-320). Emerald Group Publishing Limited.

Hill, J. (2014). Farmer-managed irrigation systems in Baltistan and Kargil. Ladhak Studies, 31, 4-23.

Hobley, M. (1996). Participatory forestry: the process of change in India and Nepal. Overseas Development Institute (ODI).

Hobley, M., \& Jha, C. (2012). Persistence and change: Review of 30 years of community forestry in Nepal. Kathmandu: HURDEC Nepal.

Huitema, D., Mostert, E., Egas, W., Moellenkamp, S., Pahl-Wostl, C., \& Yalcin, R. (2009). Adaptive water governance: Assessing the institutional prescriptions of adaptive (co-)management from a governance perspective and defining a research agenda. Ecology and Society, 14(1).

Huntjens, P., Lebel, L., Pahl-Wostl, C., Camkin, J., Schulze, R., \& Kranz, N. (2012). Institutional design propositions for the governance of adaptation to climate change in the water sector. Global Environmental Change, 22(1), 67-81.

Ives, J. D. (1989). Deforestation in the Himalayas: The cause of increased flooding in Bangladesh and northern India? Land Use Policy, 6(3), 187-193.

Ives, J. D. (2004). Himalayan perceptions: Environmental change and the well-being of mountain peoples. Routledge. 
Ives, J. D. (2012). Environmental change and challenge in the Himalaya. A historical perspective. Pirineos, 167, 29-68.

Ives, J. D., \& Messerli, B. (1989). The Himalayan dilemma: Reconciling development and conservation. Psychology Press.

Ives, J. D., Messerli, B., \& Thompson, M. (1987). Research strategy for the Himalayan Region conference conclusions and overview. Mountain Research and Development, 332-344.

Jashimuddin, M., \& Inoue, M. (2012). Community forestry for sustainable forest management: Experiences from Bangladesh and policy recommendations. Formath, 11, 133-166.

Jodha, N. S. (2005). Adaptation strategies against growing environmental and social vulnerabilities in mountain areas. Himalayan Journal of Sciences, 3(5), 33-42.

Jörgensen, K., Mishra, A., \& Sarangi, G. K. (2015). Multi-level climate governance in India: The role of the states in climate action planning and renewable energies. Journal of Integrative Environmental Sciences, 12(4), 267-283.

Jütting, J. P., Kauffmann, C., McDonnell, I., Osterrieder, H., Pinaud, N., \& Wegner, L. (2004). Decentralization and poverty in developing countries: Exploring the impact.

Karki, R., \& Gurung, A. (2012). An overview of climate change and its impact on agriculture: A review from least development country. Nepal. International Journal of Ecosystem, 2(2), 19-24.

Karki, M. B., \& Vaidya, R. (2009). Adaptation to climate change impacts and regional cooperation on water and hazards in the Himalayan Region. South Asia Water Journal, 1(2), 117-131.

Khan, N. A. (1998). A political economy of forest resource use: Case studies of social forestry in Bangladesh. Aldershot (UK): Ashgate.

Khan, N. A., Choudhury, J. K., Huda, K. S., \& Mondal, M. I. (2004). An overview of social forestry in Bangladesh. Dhaka: Bangladesh Forest Department in collaboration with University of Chittagong.

Khan, N. A., \& Harriss-White, B. (2012). The ghost in the machine: Deconstructing forest policy discourse in Bangladesh. Economic and Political Weekly, 47(17), 100-110.

Khan, H. M. (2015). Islamic law, customary law and the Afghan informal justice'. USIP.

Khan, M. R., \& Hossain, A. (2006). Regulatory vs participatory governance and environmental sustainability in Asia. Dhaka: North South University.

Kliot, N., Shmueli, D., \& Shamir, U. (2001). Institutions for management of transboundary water resources: Their nature, characteristics and shortcomings. Water Policy, 3(3), 229-255. http://www.fao.org/fileadmin/user_upload/mountain_partnership/ docs/LOW_Global_Green_Economy_RIO20.pdf

Kohler, T., Pratt, J., Debarbieux, B., Balsiger, J., Rudaz, G., \& Maselli, D. (2012). Sustainable mountain development, green economy and institutions. From Rio, 1992 to Rio 2012 and beyond. Final Draft for Rio 2012.

Kreutzmann, H. (2012). Pastoralism: A way forward or back?. In Pastoral practices in High Asia (pp. 323-336). Springer Netherlands.

Kumar, K., Singh, N. M., \& Kerr, J. M. (2015). Decentralisation and democratic forest reforms in India: Moving to a rights-based approach. Forest Policy and Economics, 51, 1-8.

Larson, A. M. (2010). Forests for people: Community rights and forest tenure reform. London: Earthscan.

Larson, A. M. (2011). Forest tenure reform in the age of climate change: Lessons for REDD+. Global Environmental Change, 21(2), 540-549.

Larson, A. M., \& Ribot, J. (2004). Democratic decentralisation through a natural resource lens: An introduction. The European Journal of Development Research, 16(1), 1-25.

Larson, A. M., \& Soto, F. (2008). Decentralization of natural resource governance regimes. Annual Review of Environment and Resources, $33,213-239$.
Larson, A. M., Brockhaus, M., Sunderlin, W. D., Duchelle, A., Babon, A., Dokken, T., et al. (2013). Land tenure and REDD+: The good, the bad and the ugly. Global Environmental Change, 23(3), 678689

Leach, M., Mearns, R., \& Scoones, I. (1999). Environmental entitlements: Dynamics and institutions in community-based natural resource management. World Development, 27(2), 225-247.

Leach, M., Bloom, G., Ely, A., Nightingale, P., Scoones, I., Shah, E., et al. (2007). Understanding governance: Pathways to sustainability. Brighton: STEPS Centre.

Lister, S. (2007). Understanding state-building and local government in Afghanistan. Crisis States Research Working Paper 14. London: Crisis States Research Centre.

Mahmoodi, S. M. (2008). Integrated water resources management for rural development and environmental protection in Afghanistan. Journal of Developments in Sustainable Agriculture, 3(1), 9-19.

Malla, Y. B. (2000). Impact of community forestry policy on rural livelihoods and food security in Nepal. Unasylva, 51(202), 37-45.

Malla, Y. B. (2001). Changing policies and the persistence of patron-client relations in Nepal: Stakeholders' responses to changes in forest policies. Environmental History, 287-307.

Maynard-Moody, S., \& Herbert, A. W. (1989). Beyond implementation: Developing an institutional theory of administrative policy making. Public Administration Review, 49(2), 137-143.

McDougall, C. L., Leeuwis, C., Bhattarai, T., Maharjan, M. R., \& Jiggins, J. (2013). Engaging women and the poor: Adaptive collaborative governance of community forests in Nepal. Agriculture and Human Values, 30(4), 569-585.

Ministry of Livestock Development. (2017). Rangeland policy, 2010. Retrieved January 17, 2017, from http://www.npafc.gov.np/content. php?id=261.

Moellenkamp, S. (2007). The "WFD-effect" on upstream-downstream relations in international river basins - Insights from the Rhine and the Elbe basins. Hydrology and Earth System Sciences Discussions, 4, 1407-1428.

Mohan, G. (1996). Adjustment and decentralization in Ghana: A case of diminished sovereignty. Political Geography, 15(1), 75-94.

Molle, F. (2009). River-basin planning and management: The social life of a concept. Geoforum, 40, 484-494.

Molle, F., \& Mamanpoush, A. (2012). Scale, governance and the management of river basins: A case study from Central Iran. Geoforum, 43(2), 285-294.

Mosse, D. (1997). The symbolic making of a common property resource: History, ecology and locality in a tank-irrigated landscape in south India. Development and Change, 28(3), 467-504.

Mowla, G. (2001). Evolution of forest management and Today's Forest Department: A perspective analysis (in Bengali), Sharanika (pp. 46-47). Dhaka: Forest Department.

Muhammed, N., Koike, M., \& Haque, F. (2008). Forest policy and sustainable forest management in Bangladesh: An analysis from national and international perspectives. New Forests, 36(2), 201216

Mustafa, D. (2010). Hydropolitics in Pakistan's Indus Basin. US Institute of Peace.

Namgyel, P. (2005). Forest policy and income opportunities from NTFP commercialisation in Bhutan. Doctoral dissertation, The University of Reading.

Narain, V. (2003). Institutions, technology and water control: Water users association and irrigation management reform in two large-scale systems in India. New Delhi: Orient Longman.

Narain, V. (2014). Local environment: The international journal of justice and sustainability. Local Environment, 19(9), 974-989.

Naustdalslid, J. (2015). Multi-level water governance-The case of the Morsa River Basin in Norway. Journal of Environmental Planning and Management, 58(5), 913-931. 
Nautiyal, S. (2011). Can conservation and development interventions in the Indian Central Himalaya ensure environmental sustainability? A socioecological evaluation. Sustainability Science, 6(2), 151-167.

Nepal, S., Flügel, W. A., \& Shrestha, A. B. (2014). Upstream-downstream linkages of hydrological processes in the Himalayan region. Ecological Processes, 3(1), 19.

Nightingale, A. J. (2002). Participating or just sitting in? The dynamics of gender and caste in community forestry. Journal of Forest and Livelihood, 2, 1.

Nightingale, A. J. (2005). "The experts taught us all we know": Professionalisation and knowledge in Nepalese community forestry. Antipode, 37(3), 581-604.

Nightingale, A. J. (2006). The nature of gender: Work, gender, and environment. Environment and planning D: Society and space, 24 (2), 165-185.

Nightingale, A. J. (2016). Adaptive scholarship and situated knowledges? Hybrid methodologies and plural epistemologies in climate change adaptation research. Area, 48(1), 41-47.

Nightingale, A. J., \& Sharma, J. R. (2014). Conflict resilience among community forestry user groups: Experiences in Nepal. Disasters, 38(3), 517-539. https://doi.org/10.1111/disa.12056.

Ning, W., Rawat, G. S., Joshi, S., Ismail, M., \& Sharma, E. (2013). High-altitude rangelands and their interfaces in the Hindu Kush Himalayas. International Centre for Integrated Mountain Development (ICIMOD).

Ning, W., Shaoliang, Y., Joshi, S., \& Bisht, N. (2016). Yak on the move: transboundary challenges and opportunities for yak raising in a changing Hindu Kush Himalayan region. In Yak on the move: Transboundary challenges and opportunities for yak raising in a changing Hindu Kush Himalayan region.

Nixon, H., Joelene, C., Saw, K. P. C., Lynn, T. A., \& Arnold, M. (2013). State and region governments in Myanmar. Myanmar Development Resource Institute-Centre for Economic and Social Development and the Asia Foundation.

Noelle-Karimi, C. (2006). Village institutions in the perception of national and international actors in Afghanistan. Amu Darya Project Working Paper No. 1. Zentrum für Entwicklungsforschung Center for Development Research, University of Bonn.

North, D. C. (1990). Institutions, institutional change and economic performance. Cambridge: Cambridge University Press.

Ojha, H. R. (2006). Techno-Bureaucratic Doxa and the challenges of deliberative governance-The case of community forestry policy and practice in Nepal. Policy and Society, 252, 131-175.

Ojha, H. R. (2014). Beyond the 'Local Community': The evolution of multi-scale politics in Nepal's community forestry regimes. International Forestry Review, 16(3), 339-353.

Ojha, H., Persha, L., \& Chhatre, A. (2009). Community forestry in Nepal: A policy innovation for local livelihoods (Vol. 913). International Food Policy Research Institute.

Ojha, H. R., Paudel, N. S., Banjade, M. R., McDougall, C., \& Cameron, J. (2010). The deliberative scientist: Integrating science and politics in forest resource governance in Nepal. In Beyond the biophysical (pp. 167-191). Springer Netherlands.

Ojha, H. R., \& Hall, A. (2013). Adaptive collaborative approaches: Traditions, foundations and frontiers. In H. R. Ojha, A. Hall, \& V. R. Sulaiman (Eds.), Adaptive collaborative approaches in natural resource governance: Rethinking participation, learning and innovation. New York: Routledge.

Ojha, H. R., Ford, R., Keenan, R. J., Race, D., Vega, D. C., Baral, H., et al. (2016a). Delocalizing communities: Changing forms of community engagement in natural resources governance. World Development, 87, 274-290.

Ojha, H. R., Khatri, D. B., Shrestha, K. K., Bhattarai, B., Baral, J. C., Basnett, B. S., et al. (2016b). Can evidence and voice influence policy? A critical assessment of Nepal's Forestry Sector Strategy,
2014. Society \& Natural Resources, 29(3), 357-373. https://doi.org/ 10.1080/08941920.2015.1122851.

Ojha, H. R., Ghimire, S., Pain, A., Nightingale, A., Khatri, D. B., \& Dhungana, H. (2016c). Policy without politics: Technocratic control of climate change adaptation policy making in Nepal. Climate Policy, 16(4), 415-433.

Olsson, P., Gunderson, L., Carpenter, S., Ryan, P., Lebel, L., Folke, C., et al. (2006). Shooting the rapids: Navigating transitions to adaptive governance of social-ecological systems. Ecology and Society, 11(1).

Ostrom, E. (1990). Governing the commons: The evolution of institutions for collective actions. Camridge: Cambridge University Press.

Ostrom, E. (1991). Rational choice theory and institutional analysis: Toward complementarity. American Political Science Review, 85 (01), 237-243.

Ostrom, E. (2010). Beyond markets and states: Polycentric governance of complex economic systems. Transnational Corporations Review, 2(2), 1-12.

Pahl-Wostl, C., Gupta, J., \& Petry, D. (2008). Governance and the global water system: A theoretical exploration. Global Governance, 14(4), 419-435.

Pandit, B. H., \& Thapa, G. B. (2004). Poverty and resource degradation under different common forest resource management systems in the mountains of Nepal. Society and Natural Resources, 17(1), 1-16.

Pasakhala, B., Ghate, R., \& Kotru, R. (2017). Integrating conservation and development in transboundary landscapes: Looking back to move forward. ICIMOD Working Paper 2017/18.

Paudel, D. (2016). Re-inventing the commons: Community forestry as accumulation without dispossession in Nepal. The Journal of Peasant Studies, 43(5), 989-1009.

Paudel, N. S., Banjade, M. R., Dahal, G. R., \& ForestAction, N. (2009). Community forestry in changing context: Emerging market opportunities and tenure rights. Kathmandu: ForestAction and CIFOR.

Pelling, M. (2011). Adaptation to climate change: From resilience to transformation. New York: Routledge.

Peters, B. G. (2015). State failure, governance failure and policy failure: Exploring the linkages. Public Policy and Administration, 30(3-4), 261-276.

Piattoni, S. (2015). Multi-level governance: Underplayed features, overblown expectation and missing linkages. In Multi-level governance: The missing linkages (pp. 321-342). Emerald Group Publishing Limited.

Pigram, J. J. (2000). Towards upstream-downstream hydrosolidarity Australia's Murray-Darling River Basin. Water International, 25(2), 222-226.

Plummer, R., Armitage, D. R., \& de Loë, R. C. (2013). Adaptive co-management and its relationship to environmental governance. Ecology and Society, 18(1), 21.

Pokharel, B. K., \& Nurse, M. (2004). Forests and people's livelihood: Benefiting the poor from community forestry. Journal of forest and Livelihood, 4(1), 19-29.

Pokharel, B. K., Branney, P., Nurse, M., \& Malla, Y. B. (2007). Community forestry: Conserving forests, sustaining livelihoods and strengthening democracy. Journal of Forest and Livelihood, 6(2), $8-19$.

Pokharel, B. K., Rayamajhi, S., \& Tiwari, K. R. (2012). Nepal's community forestry: Need of better governance. In Global perspectives on sustainable forest management (pp. 43-58). Shanghai, China: InTech.

Qin, P., Carlsson, F., \& Xu, J. (2011). Forest tenure reform in China: A choice experiment on farmers' property rights preferences. Land Economics, 87(3), 473-487.

Rahaman, M. M., \& Varis, O. (2009). Integrated water management of the Brahmaputra basin: Perspectives and hope for regional development. Natural Resources Forum, 33(1), 60-75. 
Rangan, H. (1996). From Chipko to Uttaranchal: Development, environment, and social protest in the Garhwal Himalayas, India. In R. Peet \& M. Watts (Eds.), Liberation ecologies: Environment, development and social movements (pp. 205-226). London: Routledge.

Ranjan, P. and Narain, V. (2012). Urbanization, climate change and water security: a study of vulnerability and adaptation in Sultanpur and Jhanjhrola Khera in peri-urban Gurgaon, India. (Peri-Urban Water Security Discussion Paper Series, Paper No. 3). Retrieved from SaciWATERs, India website: http://www.saciwaters.org/ periurban/discussion-paper-3.pdf.

Rasul, G. (2014). Food, water, and energy security in South Asia: A nexus perspective from the Hindu Kush Himalayan region. Environmental Science \& Policy, 39, 35-48.

Raut, N., Sitaula, B. K., \& Bajracharya, R. M. (2010). Agricultural intensification: Linking with livelihood improvement and environmental degradation in mid-hills of Nepal. Journal of Agriculture and Environment, 11, 83-94.

Regmi, B. R., \& Star, C. (2015). Identifying operational mechanisms for the mainstreaming of climate change adaptation in Nepal. Climate and Development, 6(4), 306-317.

Rest, M. (2012). Generating power: Debates on development around Arun-3 hydropower project. Contemporary South Asia, 20, 105-111.

RGOB. (1995). Forest and Nature Conservation Act of Bhutan. Royal Government of Bhutan (RGOB).

RGOB. (2007). The Land Act of Bhutan 2007. Royal Government of Bhutan (RGOB).

RGOB. (2011). The Water Act of Bhutan 2011. Royal Government of Bhutan (RGOB).

Ribot, J. C. (2003). Democratic decentralisation of natural resources: Institutional choice and discretionary power transfers in Sub-Saharan Africa. Public Administration and Development, 23, $53-65$.

Ribot, J. C. (2007). Representation, citizenship and the public domain in democratic decentralization. Development, 50(1), 43-49.

Robbins, P. (2000). The rotten institution: Corruption in natural resource management. Political Geography, 19, 423-443.

Rome, S. I. (2005). Forestry in the princely state of Swat and Kalam (North-West Pakistan): A historical perspective on norms and practices (No. 6). IP6 Working Paper.

Rosenau, J. N., von Weizsäcker, E., \& Petschow, U. (Eds.). (2004). Governance and sustainability. Exploring the roadmap to sustainability after Johannesburg. Sheffield: Greenleaf Publishing.

Sahni, H. K. (2006). The politics of water in South Asia: The case of the Indus Waters Treaty. SAIS Review of International Affairs, 26 (2), 153-165.

Saravanan, V. (2009). Decentralisation and water resources management in the Indian Himalayas: The contribution of new institutional theories. Conservation and Society, 7(3), 176-191.

Sarkar, R. (2008). Decentralised forest governance in central Himalayas: A re-evaluation of outcomes. Economic and Political Weekly, 43(18), 54-63.

Sarker, D. (2011). The implementation of the forest rights act in India: Critical issues. Economic Affairs, 31(2), 25-29.

Schild, A., \& Sharma, E. (2011). Sustainable mountain development revisited. Mountain Research and Development, 31(3), 237-241.

Shahbaz, B. (2009). Dilemmas in participatory forest management in Northwest Pakistan. A Livelihood Perspective, 25.

Shahbaz, B., \& Ali, T. (2003). Sustainable livelihoods framework and state of the Pakistan forests. In S.A. Mufti S.A., S.S. Hussain, \& A. M. Khan (Eds.), Mountains of Pakistan: Protection, potential and prospects. Islamabad, Pakistan: Global Change Impact Studies Centre.

Shabaz, B., Ali, T., \& Suleri, A. Q. (2007). A critical analysis of forest policies of Pakistan: Implications for sustainable livelihoods.
Mitigation and Adaptation Strategies for Global Change, 12(4), 441-453.

Shahbaz, B., Ali, T., \& Suleri, A. Q. (2011). Dilemmas and challenges in forest conservation and development interventions: Case of Northwest Pakistan. Forest Policy and Economics, 13(6), 473-478.

Sharma, E., \& Chettri, N. (2005). ICIMOD's transboundary biodiversity management initiative in the Hindu Kush-Himalayas. Mountain Research and Development, 25(3), 278-281.

Sharma, E., Chettri, N., \& Gyamtsho, P. (2006). Advances in community based natural resources management in the Hindu Kush-Himalayan Region. In Capitalisation and sharing of experiences on the interaction between forest policies and land use pattern in Asia (Vol. 2, pp. 9-23).

Sharma, E., Chettri, N., Gurung, J., \& Shakya, B. (2007). The landscape approach in biodiversity conservation: A regional cooperation framework for implementation of the convention on biological diversity in the Kangchenjunga landscape. ICIMOD.

Sharma, E., Chettri, N., \& Oli, K. P. (2010). Mountain biodiversity conservation and management: A paradigm shift in policies and practices in the Hindu Kush-Himalayas. Ecological Research, 25 (5), 909-923.

Sherpa, L. N., Peniston, B., Lama, W., \& Richard, C. (2003). Hands around Everest: Transboundary cooperation for conservation and sustainable livelihoods. International Centre for Integrated Mountain Development (ICIMOD).

Shrestha, K. (2012). Towards environmental equity in Nepalese community forestry. In F. D. Gordon \& G. K. Freeland (Eds.), International environmental justice: Competing claims and perspectives (pp. 97-111). Hertfordshire: ILM Publications.

Shrestha, K. (2016). Dilemmas of justice: Collective action and equity in Nepal's community forestry. New Delhi: Adroit Publisher.

Shrestha, A. B., Wahid, S. M., Vaidya, R. A., Shrestha, M. S., \& Molden, D. J. (2013). Regional water cooperation in the Hindu Kush Himalayan region. In J. Griffiths \& R. Lambert (Eds.), Free flow: Reaching water security through cooperation (pp. 65-69). UNESCO.

Shrestha, A., \& Ghate, R. (2016). Transboundary water governance in HKH: Beyond the dialectics of conflict and cooperation. International Centre for Integrated Mountain Development (ICIMOD), Hi-AWARE Working paper-7.

Sikor, T., \& Lund, C. (2009). Access and property: A question of power and authority. Development and Change, 40(1), 1-22.

Sivaramakrishnan, K. (1999). Modern forests: Statemaking and environmental change in colonial Eastern India. Stanford, CA: Stanford University Press.

Stephenson, P. (2013). Twenty years of multi-level governance: 'Where does it come from? What is it? Where is it going?'. Journal of European Public Policy, 20(6), 817-837.

Subedi, B. P. (2006). Linking plant-based enterprises and local communities to biodiversity conservation in Nepal Himalaya. New Delhi: Akhil Book Distributors.

Stiftung, F. E. (2001). Treaty of Mahakali. Retrieved from http://www. nepaldemocracy.org/documents/treaties_agreements/indo-nepal_ treaty_mahakali.htm.

Sunam, R. K., Paudel, N. S., \& Paudel, G. (2013). Community forestry and the threat of recentralization in Nepal: Contesting the bureaucratic hegemony in policy process. Society \& Natural Resources, 26 (12), 1407-1421.

Thompson, M., \& Warburton, M. (1985). Knowing where to hit it: a conceptual framework for the sustainable development of the Himalaya. Mountain Research and Development, 203-220.

Thoms, C. A. (2008). Community control of resources and the challenge of improving local livelihoods: A critical examination of community forestry in Nepal. Geoforum, 39(3), 1452-1465. 
Timsina, N. P., \& Gotame, B. (2014). Political economy of forestry sector of Nepal: Analysis of actors' engagement and policy processes. Lalitpur, Nepal: ForestAction.

Tint, K., Baginski, S. O., \& Gyi, M. K. K. (2011). Community forestry in Myanmar: Progress and potentials. Environment Conservation and Community Development Initiative, Yangon, Myanmar and School of International Development, University of East Anglia, UK.

Tiwari, P. C., \& Joshi, B. (2015). Local and regional institutions and environmental governance in Hindu Kush Himalaya. Environmental Science \& Policy, 49, 66-74.

UNDP-UNEP. (2009). Guidance note on mainstreaming environment into national development planning. Nairobi: UNPEI. Retrieved from https://www.cbd.int/doc/meetings/nbsap/nbsapcbw-seasi-01/ other/nbsapcbw-seasi-01-undp-unep-guide-en.pdf.

UNFCCC. (2015). Report of the conference of the parties on its twenty-first session, held in Paris from 30 November to 13 December 2015. Retrieved from http://unfccc.int/resource/docs/ 2015/cop21/eng/10.pdf.

Uprety, K., \& Salman, S. M. (2011). Legal aspects of sharing and management of transboundary waters in South Asia: Preventing conflicts and promoting cooperation. Hydrological Sciences Journal, 56(4), 641-661.

USAID. (2010). Bangladesh environment sector assessment and strategic analysis. Arlington: United States Agency for International Development by ECODIT.

Venkateswarlu, C. (2013). Constitutional provisions and legislations for empowering the weaker sections. Abhinav-International Monthly Refereed Journal of Research in Management \& Technology, 2, 120-129.

Vick, M. J. (2014). Steps towards an Afghanistan-Pakistan water-sharing agreement. International Journal of Water Resources Development, 30(2), 224-229.

Vij, S., \& Narain, V. (2016). Land, water \& power: The demise of common property resources in periurban Gurgaon, India. Land Use Policy, 50, 59-66.

Watto, M. A., Ali, M., Khan, A. J., \& Shahbaz, B. (2010). Stakeholder's role and interaction in the context of forestry extension interventions in the Northwest Pakistan. Pakistan Journal of Agricultural Sciences, 47(2), 173-177.

Watto, M. A., \& Mugera, A. W. (2016). Groundwater depletion in the Indus basin of Pakistan. Imperatives and repercussions. International Journal of River Basin Management, 14(4), 447-458.
Webb, E. L., \& Dorji, L. (2007). The evolution of forest related institutions in Bhutan: Adaptations of local people to the rising state in decentralization, forests, and rural communities. In E. L. Webb \& Shivakoti (Eds.), Policy outcomes in Southeast Asia. G. SAGE Publications.

Wegerich, K. (2009). Water strategy meets local reality. Afghanistan Research and Evaluation Unit.

Weiss, K., Hamann, M., Kinney, M., \& Marsh, H. (2012). Knowledge exchange and policy influence in a marine resource governance network. Global Environmental Change, 22(1), 178-188.

Wilbanks, T. J. (2007). Scale and sustainability. Climate Policy, 7(4), $278-287$.

Wirsing, R. G. (2007). Hydro-politics in South Asia: The domestic roots of interstate river Rivalry. Asian Affairs: An American Review, 34(1), 3-22.

Wirsing, R. G. (2013). Melting the geopolitical ice in south Asia. Asia Policy, 16(1), 19-25.

Wolf, A. T., \& Hamner, J. H. (2000). Trends in transboundary water disputes and dispute resolution. In M. R. Lowi \& B. R. Shaw (Eds.), Environment and security: Discourses and practices (pp. 123-148). London: Palgrave Macmillan.

Wyes, H. W., \& Lewandowski, M. (2012). Narrowing the gaps through regional cooperation institutions and governance systems. ADBI Working Paper 359. Tokyo: Asian Development Bank Institute.

$\mathrm{Xu}$, J. T. (2010). Collective forest tenure reform in China: What has been achieved so far. In World.

Zhang, B., \& Cao, C. (2015). Four gaps in China's new environmental law: Implementation and accountability will remain challenging, especially at the local level, warn Bo Zhang and Cong Cao. Nature, 517(7535), 433-435.

Zhang, H. (2016). Sino-Indian water disputes: the coming water wars? Wiley Interdisciplinary Reviews: Water, 3(2), 155-166.

Zhang, L., Heerink, N., Dries, L., \& Shi, X. (2013). Water users associations and irrigation water productivity in northern China. Ecological Economics, 95, 128-136.

Zhen, L., \& Zhang, H. (2011). Payment for ecosystem services in China: An overview. Living Reviews in Landscape Research, 5(2), 5-21.

Zittoun, P. (2015). Analysing policy failure as an argumentative strategy in the policymaking process: A pragmatist perspective. Public Policy and Administration, 30(3-4), 243-260.
Open Access This chapter is licensed under the terms of the Creative Commons Attribution 4.0 International License (http:// creativecommons.org/licenses/by/4.0/), which permits use, sharing, adaptation, distribution and reproduction in any medium or format, as long as you give appropriate credit to the original author(s) and the source, provide a link to the Creative Commons license and indicate if changes were made.
The images or other third party material in this chapter are included in the chapter's Creative Commons license, unless indicated otherwise in a credit line to the material. If material is not included in the chapter's Creative Commons license and your intended use is not permitted by statutory regulation or exceeds the permitted use, you will need to obtain permission directly from the copyright holder. 